\title{
Guidelines for the Use of Controlled Substances in the Management of Chronic Pain
}

\author{
Sairam Atluri, MD*, Mark V. Boswell, MD, PhD\#, Hans C. Hansen, MD**, Andrea M. Trescot, MD\#, \\ Vijay Singh, $M D^{\star \star \star}$, and Arthur E. Jordan, $M D^{\# \# \# ~}$
}

Controlled substance abuse has increased at an alarming rate. However, available evidence suggests a wide variance in the use of controlled substances, as documented by different medical specialties, medical boards, advocacy groups, and the Drug Enforcement Administration.

The primary objective of controlled substance guidelines by American Society of Interventional Pain Physicians (ASIPP) is to provide guidance for the use of controlled substances for the treatment of chronic pain. It is anticipated that these practical guidelines will improve quality of care, patient access, and quality of life. Additional benefits include improved treatment efficiency and efficacy, and cost containment by improving the risk-benefit ratio of treating

Guidelines for the use of controlled substances for the treatment of chronic pain are statements developed by the American Society of Interventional Pain Physicians (ASIPP) to improve quality of care, improve patient access, improve patient quality of life, improve appropriateness of care, improve efficiency and effectiveness, and achieve cost containment by improving the cost-benefit ratio.

\section{Rationale}

Available evidence documents a wide degree of variance in the prescribing patterns of controlled substances for chronic pain, as suggested by different specialties, medical boards, advocacy groups, and the

From *Tri-State Pain Management Institute, Loveland, Ohio, "Case Western Reserve University School of Medicine, Cleveland, Ohio, ${ }^{* \star}$ The Pain Relief Centers, Conover, North Carolina, \#\#The Pain Center, Orange Park, Florida, ${ }^{\star \star *}$ Pain Diagnostics Associates, Niagara, Wisconsin, and \#\#Carolina Health Specialist, Myrtle Beach, South Carolina. Address Correspondence: Sairam Atluri, MD,Tri-State Pain Management Institute, 10160 Meadowknoll Drive, Loveland, Ohio 45140, E-mail: atluri_ps@sprynet.com

Funding: There was no external funding in preparation of this manuscript. patients with chronic pain. Further goals of this manuscript are to bring consistency in opioid philosophy among the many diverse groups involved, to improve the treatment of chronic pain patients with medically appropriate controlled substances, and to reduce the incidence of drug diversion. These guidelines also reinforce the need for systematic evaluation and ongoing care of patients with chronic or persistent pain.

ASIPP controlled substance guidelines also provide a discussion of the epidemiology of chronic pain, the role of controlled substances in treating chronic pain, various aspects of drug abuse, pharmacological considerations, clinical effectiveness of controlled substances, options for treatment monitoring and drug testing and a review of

terminology used in addiction medicine.

These guidelines do not constitute inflexible treatment recommendations. It is expected that a provider will establish a plan of care on a case-by-case basis, taking into account an individual patient's medical condition, personal needs, and preferences, and the physician's experience. Based on an individual patient's needs, controlled substance prescribing and treatment different from that outlined here may be warranted. These guidelines do not represent "standard of care."

Keywords: Chronic pain, persistent pain, controlled substances, substance abuse, dependency, prescription accountability, opioids, benzodiazepines, prescription monitoring

Drug Enforcement Administration.

- Controlled substances are considered to have an important role in managing chronic non-malignant pain, even though controversial (1-66).

- Abuse of controlled substances is increasing at an alarming rate $(1-3,28$, $55,67-93)$.

Interventional pain management is the discipline of medicine devoted to the diagnosis and treatment of pain and related disorders with the application of interventional techniques in managing subacute, chronic, persistent, and intractable pain, independently or in conjunction with other modalities of treatments. Multidisciplinary or comprehensive pain management differs among specialties and may elicit confusion. An interventionalist perceives comprehensive treatment programs as programs with interventional techniques as the primary treatment modality with physical and psychological components as supplementary. In contrast, others may place primary emphasis on psychology/psychiatry, behavioral medicine, physical therapy, functional rehabilitation, or surgery.
GOALS

First, to bring consistency in controlled substance prescribing among the many diverse groups involved.

Second, to treat a legitimate pain patient with controlled substances, and reduce the risk of drug diversion, while maintaining reasonable patient access to controlled substances.

Third, to provide reasonable prescribing guidelines for physicians to reduce the risk of legal and regulatory sanctions.

Fourth, to emphasize the need for systematic evaluation and ongoing care of patients with chronic or persistent pain, and to provide an update on appropriate prescribing of controlled substances.

The benefits of these guidelines may include improved patient compliance, reduced misconceptions among providers and patients about controlled substances, the ability to manage patient expectations reasonably, and improved cooperation among patients, the providers and the regulatory agencies. 


\section{IMPLEMENTATION AND REVIEW}

The population covered by these guidelines includes all patients suffering with chronic pain requiring concurrent or independent use of controlled substances. The dates for implementation and review were established:

- Effective date - August 1, 2003

- Scheduled review -September 1, 2004

- Expiration date - July 31, 2005

\section{Chronic Pain}

The concept of chronic pain is beset with controversy, beginning with its very definition. Bonica defined chronic pain as, "pain which persists a month beyond the usual course of an acute disease or a reasonable time for any injury to hea that is associated with chronic pathologic processes that causes a continuous pain or pain at intervals for months or years" (94). Others have defined chronic pain as, "pain that exists beyond an expected time frame for healing." However, it is also recognized that, for some conditions, "healing may never occur."

Elliott et al (95) in a four-year study concluded that chronic pain is a common, persistent problem in the community with relatively high incidence and low recovery rates. They documented self-reported chronic pain in $50 \%$ of patients, equivalent to $46 \%$ of general population. Yeung et al (96) showed that musculoskeletal symptoms for multiple body parts ( 2 or more) were more prevalent (64\% of all workers) than those for single body regions (19\%). They showed that approximately $85 \%$ of lower back symptoms were associated with disorders in other body regions. Verhaak et al (97) reviewed 15 epidemiological studies of chronic pain in the adult population and concluded that chronic pain ranged from $2 \%$ to $40 \%$, with a median prevalence of $15 \%$. Anderson et al (99) reported that the incidence of persistent pain lasting for 6 months was $49 \%$ of the adult population, with functional disability in $13 \%$. Complaints of numerous pain problems in children are no exception $(100,101)$. It is also evident that the elderly suffer from pain of longer duration and with higher frequency (99, 103-105).

Lifetime prevalence of spinal pain has been reported as high as $65 \%$ to $80 \%$ in the neck and low back (104-112). Linton et al (113) estimated the prevalence of spinal pain in the general population as $66 \%$, with $56 \%$ of those reporting low back pain, $44 \%$ reporting pain in the cervical region, and $15 \%$ in the thoracic region. After the initial episode of pain, the prevalence of persistent low back and neck pain ranges from $26 \%$ to $75 \%$ (95, 114-126). Similar prevalence rates have been described for other types of pain (127-131).

Disability and cost of chronic pain are enormous $(112,127,132-137)$. Chronic pain affects people from all walks of life indiscriminately, including patients in methadone maintenance and residential treatment programs (138), further complicating the issue of controlled substance use in pain management. Thus, chronic pain is not only highly prevalent, chronic and disabling, but also expensive, regardless of how it is treated.

\section{Controlled Substance Prescribing in Chronic Pain}

Controlled prescription drugs, including opioid analgesics, anxiolytics, anti-depressants, stimulants and sedative-hypnotics play a significant and legitimate role in managing chronic pain, anxiety, depression, insomnia, and muscle spasm. However, considerable controversy exists about the use of opioids and other controlled substances for treatment of chronic pain of non-cancer origin. Inadequate treatment of pain has been attributed to a lack of knowledge about pain management options, inadequate understanding of addiction, or to fears of investigation or sanction by federal, state and local regulatory agencies $(3-26,55,80-82$, $106,139-146)$. Many authors contend that drug therapy with opioid analgesics plays an important role in pain management and should be available when needed for the treatment of all kinds of pain, including acute and cancer pain, and also noncancer pain (8-10). Even the Drug Enforcement Administration took the position that clinicians should be knowledgeable about using opioids to treat pain, and should not hesitate to prescribe them when opioids are the best clinical choice of treatment (27)

The Federation of State Medical Boards of the United States provided model guidelines for the use of controlled substances for the treatment of pain (11). These guidelines are adopted by a majority of states. In their preamble, these guidelines encourage physicians to view effective pain management as a part of quality medical practice for all patients with pain, acute or chronic. The Federation guidelines suggest that all physicians should become knowledgeable about ef fective methods of pain treatment, as well as statutory requirements for prescribing controlled substances. In addition, these guidelines acknowledge that inadequate pain control may result from physicians' lack of knowledge about pain management or an inadequate understanding of addiction, or fears of investigation or sanction by federal, state and local regulatory agencies may also result in inadequate treatment of chronic pain patients. Accordingly, the Federation developed the model guidelines to clarify the board's position on pain control, specifically as related to the use of controlled substances, to alleviate physician uncertainty about prescribing and to encourage better pain management.

Numerous causes for undertreatment of pain have been described which include lack of basic knowledge about pain management strategies, failure to apply known principles, profound reluctance to prescribe opioids, myths about opioids learned in training persist in practice with assumptions of inevitable tolerance, fear of side effects and addiction and misconceptions about dosing principles; and health care system barriers, including fear of regulatory scrutiny and prohibitive reimbursement policies, as well as patient barriers, such as fear of addiction or the assumption that pain is inevitable $(9,12,15,16)$.

Proponents of liberal opioid use for chronic pain claim that there are substantial data that support the long-term efficacy of opioids for treating chronic pain, and point to surveys indicating that drug abuse and addiction are uncommon problems among patients who have no history of abuse and who receive opioids for medical indications $(18,19)$. Further, for proponents, professional medical organizations and regulatory authorities now recognize that opioids have a justifiable and critical role in pain management (20).

\section{DRug Abuse}

In contrast to the claims of proponents, abuse of prescription controlled drugs is one facet of America's drug problem that is rapidly increasing, creating many expensive and disturbing social problems, which can be traced directly to drug dependence $(1-3,28,55$, 


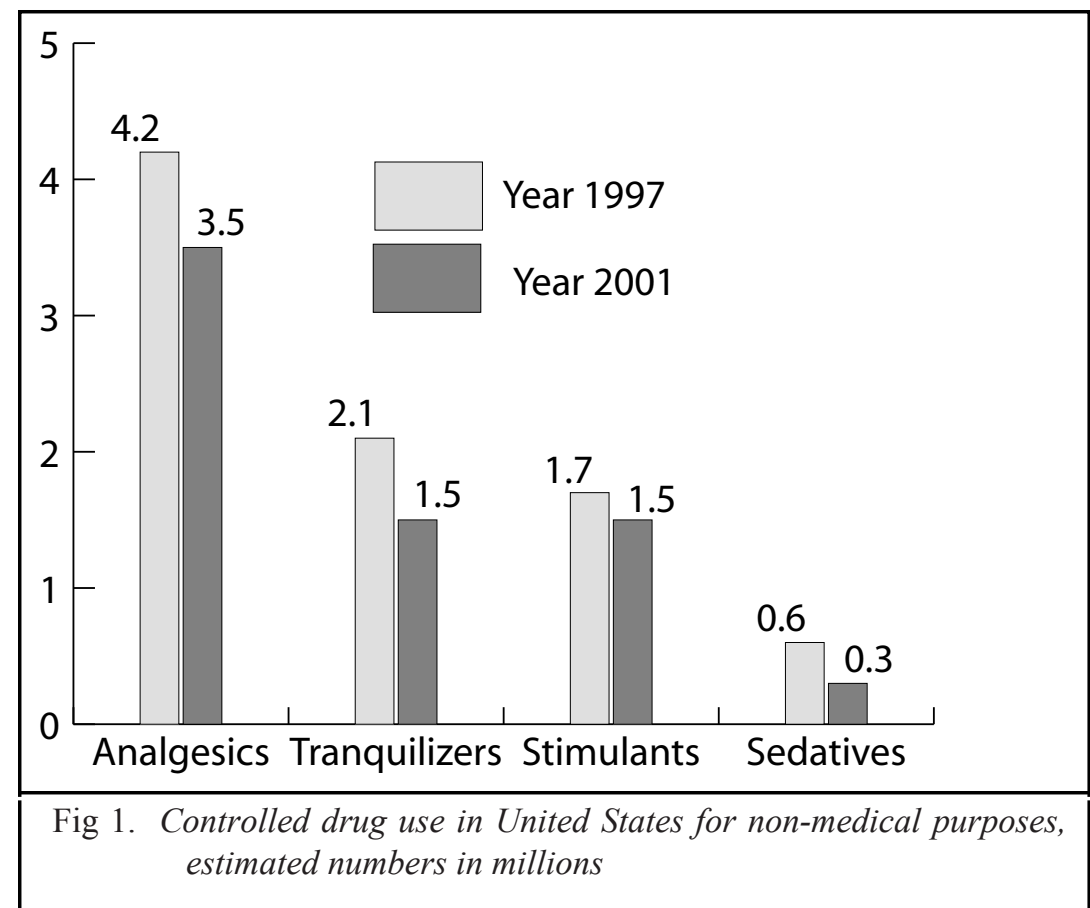

67-93). From the 1997 Household Survey on Drug Abuse, it is estimated that 76.9 million Americans, aged 12 and older have used an illicit drug at least once in their lives, representing $36.6 \%$ of the nation's household population aged 12 and older (70). In addition, over 24 million or $30 \%$ of this population reported use of an illicit drug at least once in the year prior to the interview and approximately 14 million or $17 \%$ of the population reported using an illicit drug in the month prior to interview. Based on this survey, 4.2 million people used analgesics, 2.1 million people used tranquilizers and an additional 2.3 million people used various other drugs, including sedatives, tranquilizers, etc. (Fig. 1). Further, it should be noted that the non-medical use of prescription drugs exceeds that of all illicit substances except for marijuana and hashish (71-74). A 1999 report from the National Institute of Health-National Institute on Drug Abuse (NIH-NIDA) reported that about 14.8 million Americans were current users of illicit drugs (70-74). In a report to the White House Office of National Drug Control Policy-Drug Control Strategy about the costs to society in 1995, NIH-NIDA reported that the total economic cost of drug abuse was $\$ 97.7$ billion (70-74).

The 2001 National Household Survey on Drug Abuse (67) found statisti- cally significant increases between 2000 and 2001 in the use of multiple drugs including marijuana $(4.8 \%$ to $5.4 \%)$, cocaine $(0.5 \%$ to $0.7 \%)$, and non-medical use of pain relievers $(1.2 \%$ to $1.6 \%)$ and tranquilizers $(0.4 \%$ to $0.6 \%)$. In 2001 , an estimated 15.9 million Americans age 12 years or older ( $7.1 \%$ of the population) used an illicit drug during the month immediately prior to the survey interview. By comparison, in 2000, the survey found that $6.3 \%$ of this population were current users of illicit drugs (67). In addition, this survey also reported the use of OxyContin ${ }^{\circledR}$ for non-medical purposes at least once in their lifetime increased fourfold from 1999 to 2001. An estimated 2.4 million Americans used marijuana for the first time in 2000 (67). Between 1990 and 1996 , the estimated number of new users increased from 1.4 million to 2.5 million. The number of persons with substance dependence or abuse increased from 14.5 million (6.5\% of the population) in 2000 tween 2000 and 2001, there was a significant increase in the estimated number of persons needing treatment for an illicit drug problem from 4.7 million in 2000 to 6.1 million in 2001. Of the 7.0 million current users of illicit drugs other than marijuana, 4.8 million were current users of psychotherapeutic drugs. Of those who reported current use of any psychoto 16.6 million $(7.3 \%)$ in 2001 (67). Be- therapeutics, 3.5 million used pain relievers, 1.5 million used tranquilizers, 1.0 million used stimulants, and 0.3 million used sedatives (Fig. 1).

The true extent of prescription drug abuse is unknown. However, the NHSDA shows that the initiation of non-medical prescription type drug use has been increasing (67). The annual number of new users of pain relievers has been increasing since the mid-1980s, from about 400,000 initiates to 2 million in 2000 . New users of stimulants increased from more than 200,000 in 1991 to almost 700,000 in 2000 . New users of tranquilizers have been increasing since the mid1980s, but the largest increase has been recently, from more than 700,000 new users in 1999 to almost 1 million users in 2000 with increases noted from 2000 to 2001. The number of new users of sedatives remained around 100,000 per year between 1988 and 1994. Starting in 1995, the numbers rose from 111,000 to 175,000 in 2000 (75). In 2001, it was found that 36 million Americans (16\% of persons age 12 or older) had used prescription-type drugs non-medically at least once in their lifetime. The most common category of prescription-type drugs used non-medically by adolescents in the past year was pain relievers. Pain relievers include codeine, methadone, meperidine, hydrocodone, and oxycodone.

It was shown that those adolescents and young adults who used prescription drugs non-medically in the past year had a higher rate of other illicit drug use in the past year as well. Sixty-three percent of adolescents and young adults who used prescription drugs non-medically in the past year had also used marijuana in the past year, compared with $17 \%$ of adolescents and young adults who had not used prescription drugs non-medically in the past year. Lynskey et al (68) demonstrated significant associations between early cannabis use and later drug use and abuse/dependence. According to the Drug Abuse Warning Network (DAWN) (72), the incidence of emergency department (ED) visits related to narcotic analgesic abuse has been increasing in the US and since the mid-1990s, and more than doubled between 1994 and 2001. In 2001, there were an estimated 90,232 ED visits related to narcotic analgesic abuse, a 117\% increase since 1994.

Manchikanti et al $(76,80)$, showed the prevalence of controlled substance 
abuse in interventional pain management practice settings of $18 \%$ to $24 \%$. Manchikanti et al $(78,79)$ also showed illicit drug use in $14-16 \%$ of patients without controlled substance use, and $34 \%$ of patients with controlled substance abuse. Polatin et al (77) showed current substance abuse of $19 \%$ and a lifetime prevalence of $36 \%$ in chronic low back pain. Chabal et al (1) showed that $34 \%$ of the chronic pain patients met one abuse criteria and $27.6 \%$ of the patients met three or more of the abuse criteria.

The principle drug of abuse for nearly $10 \%$ of US patients is a prescription drug (74). This is further complicated by frequent abuse of controlled substances with alcohol and illicit drugs (73, 79). The most commonly abused prescription drugs are opioids. Other controlled substances, such as benzodiazepines (e.g., diazepam, triazolam, chlordiazepoxide, alprazolam) sedative-hypnotics (e.g., secobarbital) and central nervous system stimulants (e.g., methylphenidate, amphetamine) though described to have less abuse potential than Schedule II counterparts (opioids, etc.), are also of major concern to interventional pain specialists as they appear to be widely used for non-medical purposes as well (73). It has been reported that $77.3 \%$ of suicides involve benzodiazepines (29). Fishbain et al (30), studying drug abuse and dependency in chronic pain patients, concluded that between $3.2 \%$ and $18.9 \%$ of patients have been found to have a substance abuse disorder. They also concluded that the diagnosis of abuse, drug dependency and drug addiction occur in a significant proportion of chronic pain patients.

Thus, the evidence for controlled substance abuse in chronic pain patients, as well as in the general population is overwhelming not only in the United States but also in other countries. Fishbain et al (31) and Ready et al (32) reported that patients with chronic pain not only underestimate controlled substance usage, but provided misleading information on current illicit drug usage. Overall, there is overwhelming evidence for widespread controlled substance abuse in conjunction with illicit drug usage in chronic pain patients (33-66, 78-80, 139-62). Fig. 2 shows an increasing number of emergency department mentions for oxycodone and hydrocodone.

In 1995, the Center on Addiction and Substance Abuse (CASA) estimated
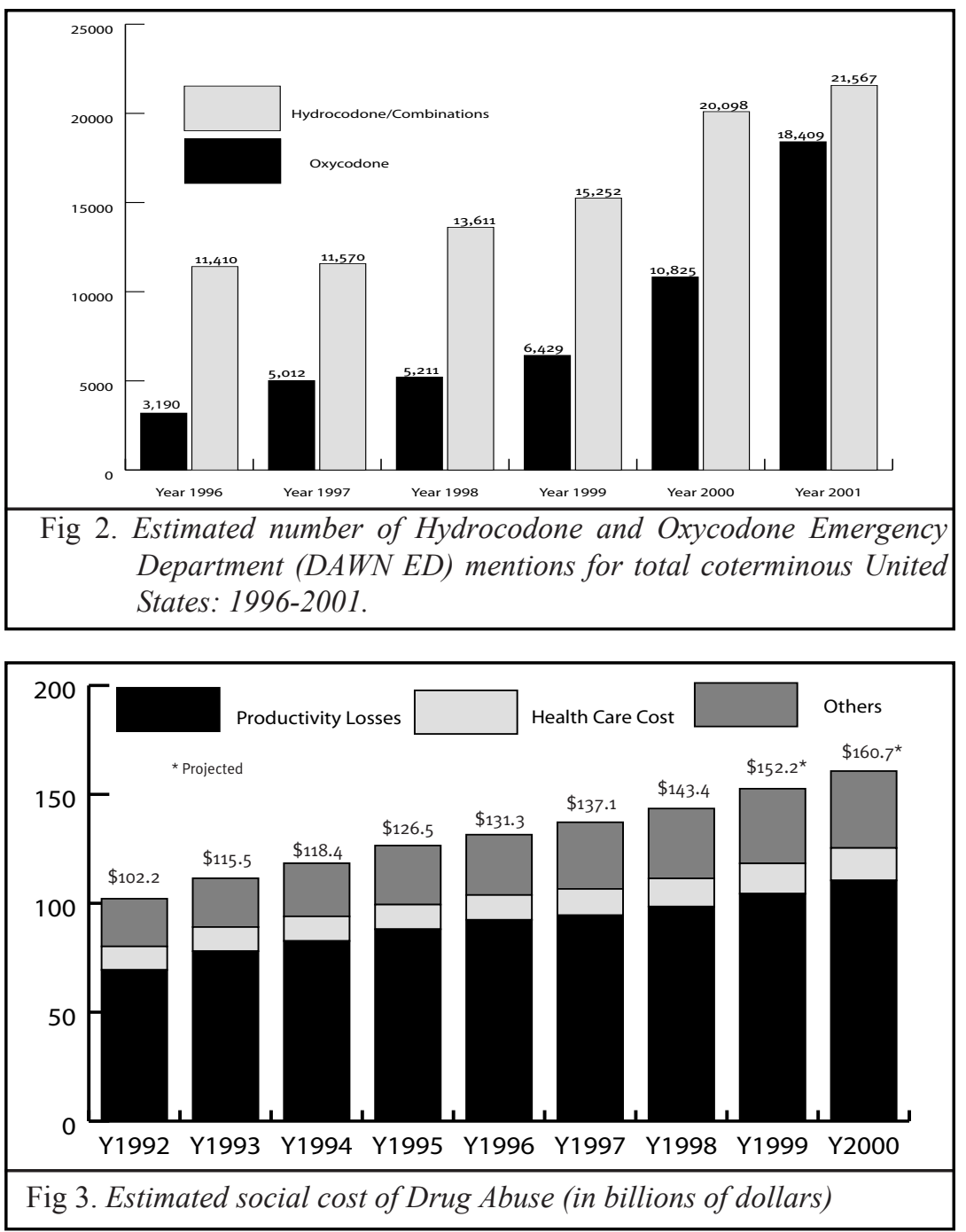

the costs of substance abuse to federal entitlement programs and found that health care and disability costs alone were $\$ 77.6$ billion, representing nearly $20 \%$ of the $\$ 430$ billion health care budget. The cost to the Medicaid program resulting from substance abuse was enormous - - an estimated $\$ 4$ billion for substance abuserelated hospital care, which, in 1994, accounted for almost $\$ 8$ billion in Medicaid expenditures (163). A study by the Office of Management and Budget estimated drug abuse costs to the United States at $\$ 300$ billion a year, including government anti-drug programs and the costs of the crime, healthcare, accidents, and lost productivity (164). In the Aid to Families with Dependent Children (AFDC), Medicaid and food stamp programs, the incidence of drug abuse varies from $9.4 \%$ to $16.4 \%$ (165). Fig. 3 shows overall costs of drug abuse from 1992-2000 (166). Fur- thermore, DAWN reported that opioid abuse has increased $85 \%$ from 1994 to 2000, 40\% from 1998 to 2000 and 19\% from 1999 to 2000. Among opioids, the most significant increases in abuse were seen with oxycodone (up 166\% since 1994), methadone (up 140\% since 1994) and hydrocodone (up 116\% since 1994) (167). Fig. 4 shows increasing opioid abuse. Fig. 5 shows increasing non-medical use of OxyContin ${ }^{\circledR}$.

The most commonly abused controlled substances include oxycodone (OxyContin $\AA$, OxyIR $\AA$, OxyFAST $\AA$, Percocet ${ }^{\circledR}, \quad$ Percodan $\AA$, Roxicodone ${ }^{\circledR}$, Tylox ${ }^{\circledR}$, and Endocet $\left.{ }^{\circledR}\right)$, hydrocodone (Lorcet $\AA$, Lortab $\AA$, Norco $\AA$, Vicoprofen ${ }^{\circledR}$, Vicodin ${ }^{\circledR}$, Zydone ${ }^{\circledR}$, and Anexsia $\left.{ }^{\circledR}\right)$, hydromorphone (Dilaudid $\AA$ ), morphine (Oramorph ${ }^{\circledR}$, Morphine ${ }^{\circledR}$, MS Contin ${ }^{\circledR}$, MS IR ${ }^{\circledR}$, Kadian ${ }^{\circledR}$, and Roxanol®), methadone (Dolophine ${ }^{\circledR}$ and 

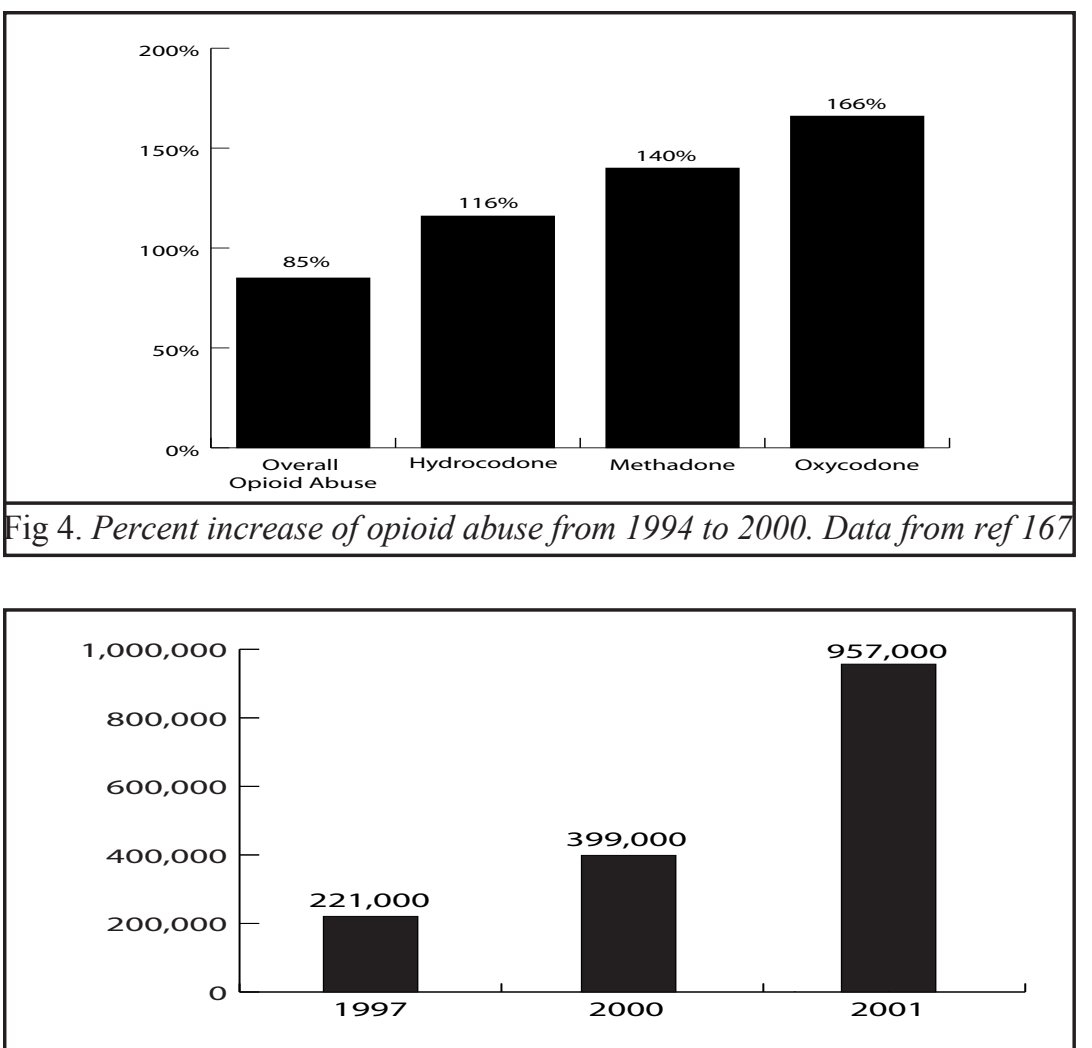

Fig 5. Non medical use of OxyContin among U.S. population

Methadose ${ }^{\circledR)}$ codeine (Codeine, Tylenol with codeine ${ }^{\circledR}$, Empirin with codeine ${ }^{\circledR}$, and Fiorinal with codeine $\left.{ }^{\circledR}\right)$, clonazepam (Klonopin $\AA)$, alprazolam (Xanax $\AA)$, lorazepam (Ativan $\left.{ }^{\circledR}\right)$, diazepam (Valium ${ }^{\circledR}$ ), and carisoprodol (Soma $\left.{ }^{\circledR}\right)$.

The diversion of prescription controlled substances to illicit channels is a public health and safety issue. Controlled substances are diverted in numerous ways, including through theft, forgery and counterfeiting of prescriptions, illegal sales of prescriptions and drugs, fraudulent activities that victimize physicians, pharmacies and patients, and by a small percentage of physicians who write prescriptions indiscriminately because they are dishonest, disabled, deceived, or outdated in their practices $(8,45-66,80,139-142)$. Misuse and abuse of prescription controlled substances leads to serious health consequences, including drug dependence, and overdose (45).

\section{Rationale for Use of Controlled Substances in Chronic Pain}

Chronic pain is viewed as a multidimensional problem. The current- al domains including structural, psychological, and social, it is of paramount importance to define which factors are most important for the purpose of treatment in a chronic pain patient. Multiple psychological factors may be coexistent or consequences of persistent pain. In addition to depression, anxiety, and somatization, other problems include decreased socialization, sleep disturbances, impaired function, and increased healthcare utilization costs.

Pharmacotherapy with controlled substances is the most common treatment to control pain. While pharmacotherapy is the most effective means in acute and malignant pain, it may not suffice in chronic or persistent pain as the mainstay of treatment. Generally, greater reductions in pain and improvements in function are usually obtained by a combination of pharmacological and non-pharmacological treatments, including modalities directed at precise diagnosis and management of structural problems underlying the chronic pain. Thus, patients with persistent pain may require various modalities of treatments including medications.

The controlled substances utilized in managing chronic or persistent pain are opioids, depressants, and stimulants. These include, apart from anti-depressants and anti-convulsants, benzodiazepines, barbiturates, muscle relaxants, and stimulants. Commonly utilized prescription-controlled substances in interventional pain management are listed in Table 1.

\section{Pharmacological Considerations} and various non-specific problems, such as emotional instability, anger and loss of self-esteem. The association between chronic pain, depression, generalized anxiety disorder and somatization disorders has been explored vigorously and clearly remains a complex issue. Major depressive disorder has been shown to be present in $22 \%$ to $58 \%$ chronic pain patients $(172-176,180)$, in contrast to $4 \%$ to $5 \%$ of the patients without chronic pain. Similarly, anxiety disorders have been shown to be present in $20 \%$ to $54 \%$ of patients with chronic pain, compared to $0 \%$ to $14 \%$ of the population without chronic pain $(173,175-178,180)$.

Thus, the clinical manifestations of persistent pain are commonly multifactorial. Due to the complex nature of chronic or persistent pain and complex interplay among a multitude of factors across sever-

\section{Opioid Analgesics}

Opioids are analgesics affecting nociception by modulation of ascending and descending pathways. Opioids may be classified by their function as agonists, mixed agonists-antagonists, or antagonists as well as by their actions at $\mu, \kappa$, and $\delta$ receptors (Table 2 ).

Stimulation of $\mu$ receptors causes respiratory depression, euphoria, decreased gastrointestinal motility, and physical dependence. Stimulation of $\kappa$ receptors can cause psychotomimetic and dysphoric effects. Stimulation of $\delta$ receptors can cause dysphoria and respiratory depression. Pure opioid agonists (e.g., morphine, hydromorphone, fentanyl) stimulate $\mu$ receptors and are the most potent analgesics. As the dose is increased, analgesia occurs in a log linear fashion; the degree of 
Table 1. Common prescription controlled substances-Federal Schedule II, III, and IV drugs

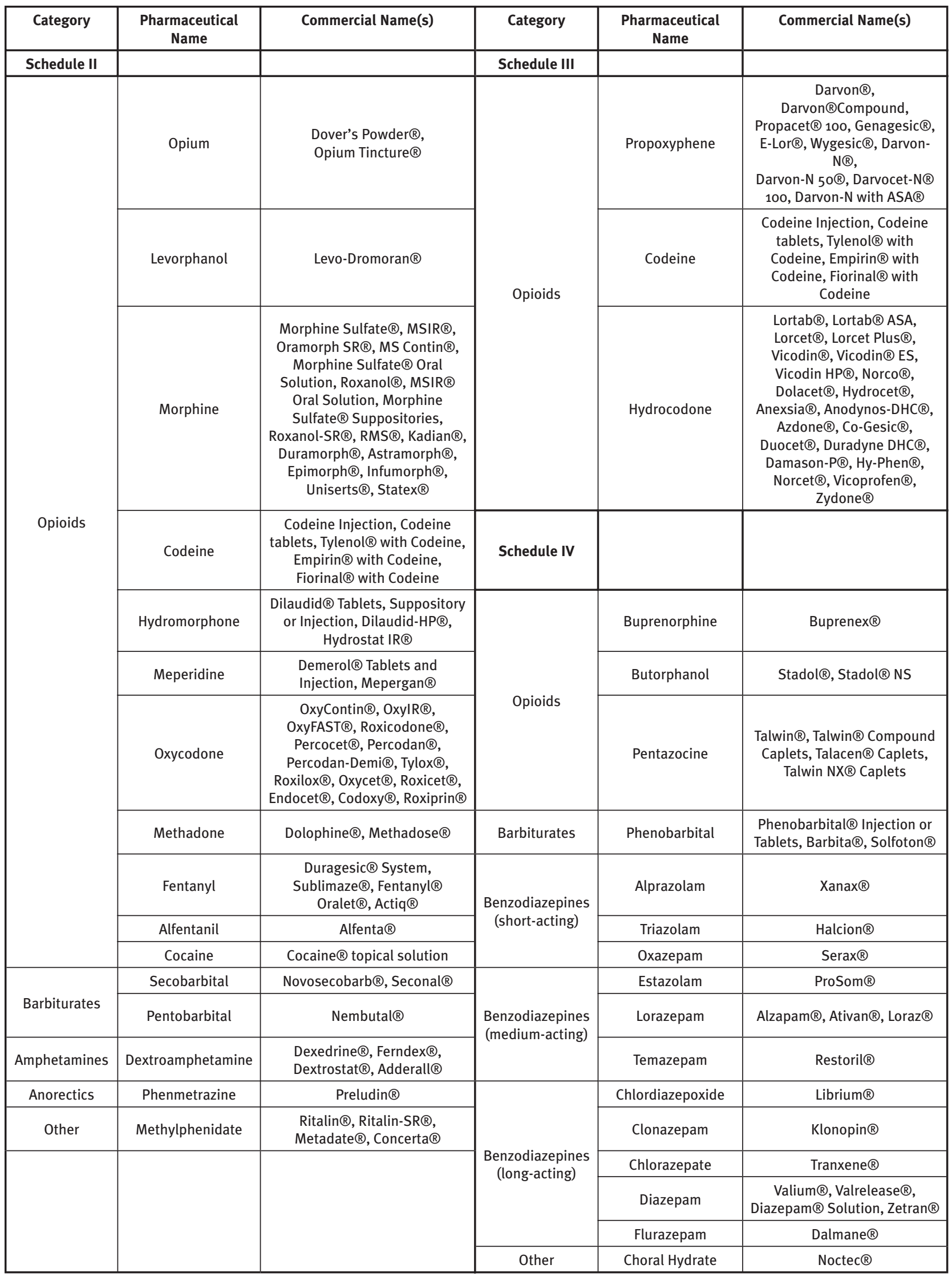


analgesia induced is limited only by intolerable dose-related adverse effects (182). In contrast, opioid agonists/antagonists and opioid partial agonists exhibit a ceiling effect on the degree of analgesia that they can produce (183). In addition, opiate agonist/antagonists and partial agonists can precipitate opioid withdrawal reactions (183). Further, the respiratory depressant effects of partial agonists are not completely reversed with naloxone.

Traditionally, opioid preparations have been classified into two categories: weak or strong opioid analgesics. Weak opioids include codeine, dihydrocodeine, hydrocodone, propoxyphene, meperidine, and pentazocine (184). Their effectiveness is limited by an increased incidence of side effects at higher dosages, which include nausea and constipation with codeine, central nervous system excitation with propoxyphene, dysphoric effects with pentazocine. Oxycodone and hydrocodone also have been considered as weak analgesics because of their use in fixed combination preparations containing acetaminophen or nonsteroidal anti-inflammatory drugs (184). It should be noted that when oxycodone is used as a single agent, it has no ceiling effect for analgesia. In some patients oxycodone may be better tolerated than oral morphine, and is considered a potent alternative to morphine. Further, it should be noted that some analgesic combination formulations do not provide $650 \mathrm{mg}$ of aspirin or acetaminophen, which are the usual optimal analgesic doses (182). Instead, the formulation may contain less or more than this amount of the non-opiate. Thus, physicians must exercise care to avoid underdosing or overdosing with the non-opiate when such formulations are used. If a physician feels that it is medically necessary to prescribe more opiate than can be provided in a fixed dose combination formulation, this may be achieved by prescribing the pure opioid alone in combination with the appropriate dose of the over the counter analgesic (182). Table 3 summarizes various pharmacologic properties of the opioid analgesics.

The drugs with a wide therapeutic range and without a ceiling effect for analgesia include morphine, hydromorphone, methadone, oxycodone and fentanyl. In this category, higher doses produce an increasing level of analgesia. Long-acting opioids including controlled-release morphine, as well as controlled-release oxycodone.

\section{Non-opioid Controlled Substances}

Benzodiazepines are the most important class of anxiolytics frequently prescribed for the short-term symptomatic treatment of anxiety and sleep disorders. Their effects involve transmission of norepinephrine, serotonin, dopamine, and gamma-aminobutyric acid (GABA). However, these drugs do not produce significant analgesic effects. Indications for their use in chronic pain include anxiety, which frequently may accompany chronic pain, as well as muscle tension and insomnia. Among the benzodiazepines, alprazolam, triazolam, and oxazepam, are classified as short-acting, estazolam, lorazepam, and temazepam are classified as medium-acting, whereas, chlordiazepoxide, clonazepam, chlorazepate, diazepam, and flurazepam are classified as long-acting benzodiazepines.

Before the advent of benzodiazepines, barbiturates were used extensively as sedative-hypnotics and anti-anxiety drugs. They are structurally related compounds that act throughout the central nervous system, particularly in the mesencephalic reticular activating system, which controls CNS arousal mechanisms. Barbiturates decrease presynaptic and postsynaptic membrane excitability. The exact mechanism of action at these sites is not known. Further, it is also not clear which cellular and synaptic actions result in sedative-hypnotic effects. Barbiturates produce dose-dependant CNS depression, from mild sedation to coma and death. Barbiturates facilitate the actions of GABA. Central effects include respiratory depression and suppression of gastrointestinal motility. They are also anticonvulsants. The principle anticonvulsant effect involves neuronal excitability, which raises the seizure threshold. Barbiturate-induced sleep differs from physiologic sleep by decreasing rapid eye movement (REM) sleep cycles.

Table 2. Agonists and antagonists of major types of opioid receptor subtypes

\begin{tabular}{|l|c|c|c|}
\hline \multicolumn{1}{|c|}{ Drug } & $\mu$ & $\boldsymbol{\delta}$ & \multicolumn{1}{c|}{$\boldsymbol{\kappa}$} \\
\hline Opioid peptides & & Agonist & \\
\hline Enkephalins & Antagonist & Agonist & \\
\hline$\beta$-Endorphin & Agonist & \\
\hline Dynorphin & Weak agonist & Weak agonist & \\
\hline Agonist & Weak agonist & \\
\hline Codeine & Agonist & & \\
\hline Fentanyl, sufentanil, & Agonist & & \\
\hline Alfentanil, remifentanil & Agonist & & \\
\hline Meperidine & Agonist & Weak agonist & \\
\hline Methadone & & & \\
\hline Morphine & Partial agonist & & \\
\hline Agonist-antagonists & Antagonist or partial agonist & & Agonist \\
\hline Buprenorphine & Antagonist & Antagonist & Antagonist \\
\hline Pentazocine & & & \\
\hline Antagonist & & & \\
\hline Naloxone & & & \\
\hline
\end{tabular}


Table 3. Pharmacologic aspects of narcotic analgesics

\begin{tabular}{|c|c|c|}
\hline Opiate & Metabolism & Comments \\
\hline $\begin{array}{l}\text { Morphine } \\
\text { (Morphine Sulfate, MSIR, Oramorph } \\
\text { SR, MS Contin, Morphine Sulfate Oral } \\
\text { Solution, Roxanol, MSIR Oral Solution, } \\
\text { Morphine Sulfate Suppositories, } \\
\text { Roxanol-SR, RMS, Kadian, Duramorph, } \\
\text { Astramorph, Epimorph, Infumorph, } \\
\text { Uniserts, Statex) } \\
\text { Plasma half-life }-2-3.5 \text { hrs } \\
\text { Duration of action }-3-6 \text { hrs }\end{array}$ & $\begin{array}{l}\text { Two major metabolites: } M_{3} G \text { and } M 6 G \text {, which can } \\
\text { cause adverse effects, if they accumulate. }\end{array}$ & $\begin{array}{l}\text { Morphine crosses the blood-brain barrier at a low } \\
\text { rate, with small quantities of morphine crossing } \\
\text { the blood-brain barrier in adults. Morphine-6- } \\
\text { glucuronide may accumulate after continuous } \\
\text { dosing in patients with renal failure, leading } \\
\text { to enhanced, prolonged opiate activity. Thus, } \\
\text { morphine dose may need to be reduced in patients } \\
\text { with significant renal and/or hepatic impairment or } \\
\text { in the elderly to avoid adverse effects (186). }\end{array}$ \\
\hline $\begin{array}{l}\text { Meperidine } \\
\text { (Demerol, Mepergan) } \\
\text { Plasma half-life }-2-4 \text { hrs } \\
\text { Duration of action }-2-4 \text { hrs }\end{array}$ & $\begin{array}{l}\text { Meperidine is metabolized to Normeperidine. } \\
\text { Normeperidine has a half-life of } 15-30 \text { hours, is } \\
\text { renally excreted, and causes seizures, myoclonus, } \\
\text { tremors, and central nervous system irritability } \\
\text { when it accumulates. }\end{array}$ & $\begin{array}{l}\text { Meperidine is a relatively weak opioid with } \\
\text { significant anti-cholinergic and local anesthetic } \\
\text { properties, with only } 10 \% \text { efficacy of morphine. } \\
\text { The oral-to-parental ratio is 4:1. Meperidine should } \\
\text { not be administered in patients with impaired renal } \\
\text { function. It should be administered with caution } \\
\text { in elderly. Normeperidine is accumulated after } \\
\text { long-term meperidine administration, particularly } \\
\text { in patients with renal dysfunction, and may cause } \\
\text { central nervous system excitatory effects, which } \\
\text { may produce naloxone-irreversible multifocal } \\
\text { myoclonus and grand-mal seizures. Short-term } \\
\text { administration of meperidine may be associated } \\
\text { with mild dysphoria. Meperidine is contraindicated } \\
\text { in patients on monamine oxidase inhibitors, which } \\
\text { may result in severe respiratory depression, } \\
\text { hyperpyrexia, central nervous system excitation, } \\
\text { delirium and seizures (184). }\end{array}$ \\
\hline $\begin{array}{l}\text { Methadone } \\
\text { (Dolophine, Methadose) } \\
\text { Plasma half-life }-7-11 \text { hrs or } 15-30 \text { hrs } \\
\text { Half-life may increase to } 128 \text { hours } \\
\text { with repeated dosing } \\
\text { Duration of action - } 10 \text { hrs }\end{array}$ & $\begin{array}{l}\text { Long half-life correlates with prolonged duration of } \\
\text { adverse effects, if they occur. }\end{array}$ & $\begin{array}{l}\text { Methadone offers several advantages over } \\
\text { morphine: } \\
\text { - Extended suppression of withdrawal } \\
\text { symptoms in opioid dependent patients } \\
\text { - Slower development of tolerance and physical } \\
\text { dependence } \\
\text { - Milder withdrawal symptoms after abrupt } \\
\text { termination of the drug (186) }\end{array}$ \\
\hline $\begin{array}{l}\text { Levorphanol Tartrate } \\
\text { (Levo-Dromoran) } \\
\text { Plasma half-life }-11-16 \mathrm{hrs} \\
\text { Duration of action }-6-8 \mathrm{hrs}\end{array}$ & $\begin{array}{l}\text { Long half-life correlates with prolonged duration of } \\
\text { adverse effects, if they occur. }\end{array}$ & $\begin{array}{l}\text { Levorphanol may contain sodium metabisulfite, } \\
\text { which may cause allergic reactions or anaphylaxis } \\
\text { in susceptible individuals. One } \mathrm{mg} \text { of parental } \\
\text { levorphanol is equivalent to } 5 \mathrm{mg} \text { of parental } \\
\text { morphine sulfate in analgesic efficacy. Levorphanol } \\
\text { produces less nausea, vomiting, and constipation } \\
\text { and more sedation and smooth muscle stimulation } \\
\text { than equianalgesics doses of morphine sulfate. }\end{array}$ \\
\hline $\begin{array}{l}\text { Hydromorphone } \\
\text { (Dilaudid, Dilaudid-HP, Hydrostat IR) } \\
\text { Plasma half-life }-2-3 \text { hrs } \\
\text { Duration of action }-4-5 \text { hrs }\end{array}$ & $\begin{array}{l}\text { The duration of analgesic action of hydromorphone } \\
\text { is similar to morphine ( } 3-4 \text { hours), and the } \\
\text { metabolic pathways for its degradation are similar } \\
\text { to morphine. Hydromorphone is metabolized } \\
\text { primarily to hydromorphone-3-glucuronide }\left(\mathrm{H}_{3} \mathrm{G}\right) \text {, } \\
\text { which, similar to the corresponding } \mathrm{M}_{3} \mathrm{G} \text {, is not } \\
\text { only devoid of analgesic activity, but also evokes } \\
\text { a range of dose-dependent excitatory behaviors, } \\
\text { including allodynia, myoclonus, and seizures in } \\
\text { animal models. }\end{array}$ & $\begin{array}{l}\text { The oral-to-parental ratio of hydromorphone is } 5 \text { : } \\
1 \text {, and the oral bioavailability of hydromorphone } \\
\text { is about } 30 \% \text { to } 40 \% \text {. Its long half-life correlates } \\
\text { with prolonged duration of adverse effects, if they } \\
\text { occur. }\end{array}$ \\
\hline
\end{tabular}


Table 3. Pharmacologic aspects of narcotic analgesics (Continued)

\begin{tabular}{|c|c|c|}
\hline Opiate & Metabolism & Comments \\
\hline $\begin{array}{l}\text { Oxycodone } \\
\text { (OxyContin, OxylR, OxyFAST, } \\
\text { Roxicodone, Percocet, Percodan, } \\
\text { Percodan-Demi, Tylox, Roxilox, Oxycet, } \\
\text { Roxicet, Endocet, Codoxy, Roxiprin) } \\
\\
\text { Plasma half-life }-2-3 \text { hrs } \\
\text { Duration of action }-4-6 \text { hrs }\end{array}$ & $\begin{array}{l}\text { Oxycodone undergoes oxidative hepatic } \\
\text { metabolism and conjugation into inactive } \\
\text { metabolites. Oxycodone is conjugated extensively } \\
(15 \% \text { to } 80 \% \text { of the total dose) in the liver, and the } \\
\text { minority undergoes demethylation and oxidation } \\
\text { by multiple hepatic pathways into noroxycodone, } \\
\text { oxymorphone, oxycodols, and their respective } \\
\text { oxides (184). Less than } 10 \% \text { of oxycodone is } \\
\text { excreted in the urine. }\end{array}$ & $\begin{array}{l}\text { Oxycodone is generally considered as a weak } \\
\text { analgesic because of its use in a fixed combination } \\
\text { with acetaminophen and non-steroidal anti- } \\
\text { inflammatory drugs. When oxycodone is used } \\
\text { as a single oral agent, however, it has no ceiling } \\
\text { effect for analgesia. Oxycodone seems to produce } \\
\text { fewer side effects than morphine after oral } \\
\text { administration. } \\
\text { Oxycodone is considered a schedule II opioid } \\
\text { compared to hydrocodone, which is considered } \\
\text { a schedule III narcotic. Abuse potential of } \\
\text { oxycodone is considered higher than hydrocodone } \\
\text { and similar to morphine. }\end{array}$ \\
\hline $\begin{array}{l}\text { Fentanyl (Duragesic, Sublimaze, } \\
\text { Fentanyl Oralet, Actiq) } \\
\text { Plasma half-life }-1.5-6 \text { hrs } \\
\text { Duration of action }-1-2 \text { hrs }\end{array}$ & $\begin{array}{l}\text { Transdermal fentanyl undergoes extensive } \\
\text { metabolism, primary by hepatic pathways. }\end{array}$ & $\begin{array}{l}\text { Fentanyl is administered transdermally in chronic } \\
\text { pain, due to its strong lipophilic properties. }\end{array}$ \\
\hline $\begin{array}{l}\text { Codeine } \\
\text { (Codeine, Tylenol with Codeine, } \\
\text { Empirin with Codeine, Fiorinal with } \\
\text { Codeine, Codeine Injection, Codeine } \\
\text { Tablets) } \\
\text { Plasma half-life }-3 \text { hrs } \\
\text { Duration of action }-4-6 \text { hrs }\end{array}$ & $\begin{array}{l}\text { Must be hepatically converted by CYP2D6 enzyme } \\
\text { to morphine. However, } 7-10 \% \text { of Caucasian } \\
\text { population lacks this enzyme. Codeine is } \\
\text { metabolized predominantly by glucuronidation } \\
\text { to codeine-6-glucoronide (C6G). Other metabolic } \\
\text { pathways, though minor, include n-demethylation } \\
\text { to norcodeine and o-demethylation to morphine } \\
(187) \text {. There is increasing evidence that the } \\
\text { analgesic effect of codeine is mediated by its o- } \\
\text { demethylated metabolic morphine (188). }\end{array}$ & $\begin{array}{l}\text { Codeine is classified as a weak opioid due to } \\
\text { its side effects and also of its use in a fixed } \\
\text { combination with acetaminophen and non- } \\
\text { steroidal anti-inflammatory drugs. Significant } \\
\text { nausea and constipation are associated with } \\
\text { codeine administration in higher doses. Thus, } \\
\text { doses of codeine greater than } 65 \mathrm{mg} \text { are not } \\
\text { appropriate because of the increasing side effects. }\end{array}$ \\
\hline $\begin{array}{l}\text { Hydrocodone } \\
\text { (Lortab, Lortab ASA, Lorcet, Lorcet } \\
\text { Plus, Vicodin, Vicodin ES, Vicodin HP, } \\
\text { Norco, Dolacet, Hydrocet, Anexsia, } \\
\text { Anodynos-DHC, Azdone, Co-Gesic, } \\
\text { Duocet, Duradyne DHC, Damason-P, } \\
\text { Hy-Phen, Norcet, Vicoprofen, Zydone) } \\
\text { Plasma half-life- }-3.3-4.5 \mathrm{hrs} \\
\text { Duration of action }-4-6 \mathrm{hrs}\end{array}$ & $\begin{array}{l}\text { Hydrocodone undergoes extensive hepatic } \\
\text { conjugation and oxidative degradation to a variety } \\
\text { of metabolites excreted mainly in the urine. The } \\
\text { major metabolites of hydrocodone excreted } \\
\text { into urine are conjugates of dihydrocodeine } \\
\text { and nordihydrocodeine (both conjugated } \\
\text { to approximately } 65 \% \text { ) (184). Some of the } \\
\text { hydrocodone metabolites (DHM, hydromorphone, } \\
\text { dihydrocodeine) are pharmacologically active on } \\
\text { the opioid receptors and may contribute, in various } \\
\text { degrees, to analgesic activity of hydrocodone } \\
\text { or produce unexpected side effects in renal } \\
\text { dysfunction with impaired excretion. } \\
\end{array}$ & $\begin{array}{l}\text { Hydrocodone is the most commonly used narcotic } \\
\text { analgesic due to its schedule III controlled } \\
\text { substance status compared to oxycodone } \\
\text { (schedule II). Hydrocodone is classified as mild } \\
\text { weak, or low potency opiate because the maximum } \\
\text { daily dose of opiate that can be administered is } \\
\text { limited by the maximum safe dose of the non- } \\
\text { narcotic component of the formulation. }\end{array}$ \\
\hline $\begin{array}{l}\text { Propoxyphene } \\
\text { (Darvon, Darvon Compound, Propacet } \\
\text { 100, Genagesic, E-Lor, Wygesic, } \\
\text { Darvon-N, Darvon-n 50, Darvocet-N } \\
\text { 100, Darvon-N with ASA) } \\
\\
\text { Plasma half-life }-6-12 \text { hrs } \\
\text { Duration of action }-3-4 \text { hrs }\end{array}$ & $\begin{array}{l}\text { Propoxyphene is a synthetic narcotic analgesic, } \\
\text { structurally related to methadone. It is degraded } \\
\text { mainly in the liver; about } 1 / 25 \text { of a dose is } \\
\text { metabolized or norpropoxyphene, an active } \\
\text { metabolite. The drug is excreted in the urine (189). }\end{array}$ & $\begin{array}{l}\text { Some studies have suggested that its efficacy is } \\
\text { similar to that of Aspirin or acetaminophen alone, } \\
\text { but drug accumulation, neuroexcitatory effects, } \\
\text { and ataxia or dizziness may add unnecessary } \\
\text { morbidity in older patients. Many authors suggest } \\
\text { that the other analgesic strategies are more } \\
\text { appropriative for patients with persistent mild to } \\
\text { moderate pain than propoxyphene (190-192). Its } \\
\text { metabolite norpropoxyphene possess cardiac } \\
\text { toxicity and long half-life of } 30 \text { to } 60 \text { hours. } \\
\text { Propoxyphene itself can produce seizures after } \\
\text { overdosage, and these seizures are reversible by } \\
\text { naloxone administration. }\end{array}$ \\
\hline $\begin{array}{l}\text { Pentazocine } \\
\text { (Talwin, Talwin Compound Caplets, } \\
\text { Talacen Caplets, Talwin NX Caplets) } \\
\text { Plasma half-life }-4 \text { hrs } \\
\text { Duration of action }-3-5 \text { hrs }\end{array}$ & $\begin{array}{l}\text { Pentazocine is a semisynthetic drug. It is } \\
\text { metabolized almost exclusively in the liver to } \\
\text { inactive glucuronides and oxidation of the terminal } \\
\text { methyl group. }\end{array}$ & $\begin{array}{l}\text { It is a weak agonist antagonist. It interacts with } \\
\kappa \text {-opioid receptors and } \sigma \text { - receptors. It has been } \\
\text { described that these properties are responsible } \\
\text { for the dysphoric and psychotomimetic effects of } \\
\text { pentazocine. }\end{array}$ \\
\hline
\end{tabular}


Stimulants include amphetamines, phenmetrazine, methylphenidate, and various other drugs including Adipex, Cylert, Didrex, Ionamin, and Tenuate, etc. Indications for stimulants are limited, but may include symptomatic control of sedation caused by opioids; this use is justified more commonly in palliative care and cancer pain treatment.

\section{Adverse Effects of Controlled Substances}

All drugs utilized in the management of chronic pain have side effects, can produce complications, and cause adverse drug interactions. Adverse effects caused by opioids range from relatively minor annoyances, such as itching to life-threatening complications such as respiratory depression. Common adverse effects in clinical practice include pruritus, nausea and vomiting, constipation, and sedation. These adverse effects may occasionally limit opioid administration when severe.

Pruritus may occur with all types of opioid administration and partially responds to antihistamine administration. Nausea and vomiting are very common after opioid administration, related to stimulation of receptors in the chemoreceptor trigger zone in the medulla. Sedation may be a significant clinical problem with high-dose opioids and rapidly accelerating dosages. Most patients do not require any specific treatment for this side effect, as it tends to disappear with time. Respiratory depression is a feared complication that is rarely seen with chronic opioid therapy. Fear of this complication often results in undertreatment, specifically in opioid-tolerant individuals. However, sedation usually precedes the onset of clinically significant respiratory depression. Opioids reduce brain stem responsiveness to $\mathrm{CO}_{2}$ and thereby depress respiratory drive. This is the most potentially dangerous adverse effect of opioids, however, it is a rare occurrence in a clinically controlled environment. However, rapid titration of an opioid in an opioid-naïve patient, or acute overdose, even in a patient taking large doses of an opioid on a chronic basis, can result in life-threatening respiratory depression. This may also be a problem in patients who abuse drugs, particularly alcohol.

The most problematic side effect with chronic opioid exposure is constipation due to $\mathrm{mu}$ receptor stimulation. Constipation and miosis are not subject to the development of tolerance.
Urinary retention is more common in the elderly and patients taking tricyclic antidepressants. Pruritus is a common, but self-limiting problem that resolves after a few days of therapy and easily responds to antihistamines, such as diphenhydramine. In the acute setting, small doses of parenteral naloxone (eg, $0.1 \mathrm{mg}$ ) may reverse the itching associated with spinally administered opioids.

All benzodiazepines produce doserelated sedation. CNS depressant effects are potentiated by alcohol, opioids and barbiturates.

\section{Clinical Effectiveness of Controlled SUBSTANCES}

Moulin et al (58) in a randomized trial evaluating oral morphine with chronic non-malignant pain, reported greater control of pain than patients in the placebo group, with low risk of addiction. However, there was no improvement in psychological functioning. The study was a short-term, nine weeks crossover trial. Arkinstall et al (199) also in a randomized placebo-controlled trial utilizing controlled-release codeine, reported significant reduction in both pain and pain-related disability. The study was conducted in 30 patients for 7 days with crossover design. Jamison et al (200) in a randomized open trial, comparing two opioid regimens with either set-dose oxycodone or titrated-dose oxycodone and sustained release morphine sulfate, reported significant pain relief but failed to show any differences in sleep patterns or activity status. They also showed that only one patient in the 36-patient sample demonstrated behavior consistent with abuse. Taub (201) in 313 patients with somatic and neuropathic pain, administered mean doses of $10 \mathrm{mg}$ to $20 \mathrm{mg}$ of oral methadone up to six years showing that patients showed generalized benefit. Abuse was seen in 13 of 313 patients. Portenoy and Foley (202) in a study of 38 patients with mixed diagnoses with median treatment of three to four years reported adequate or partial relief of pain in 24 patients with very little functional improvement; abuse was seen with two patients. Tennant et al (203) evaluated 52 patients with mixed diagnosis with $10 \mathrm{mg}$ to 240 $\mathrm{mg}$ of oral methadone with average treatment lasting over twelve years. They reported adequate or partial relief of pain in all patients. Zenz et al (56) in evaluation of 100 patients with mixed pain problems with oral morphine ranging from $20 \mathrm{mg}$ to $2000 \mathrm{mg}$ with a mean duration of treatment of 224 days, reported good or partial pain relief in $79 \%$ of the patients with overall improvement in performance status and no abuse. Rowbotham et al (24) reported on the efficacy of opioids in reducing the severity of treatment - refractory neuropathic pain in patients with either a central or peripheral neuropathic pain syndrome, in a double-blind, randomized, controlled trial, and observed a $36 \%$ reduction in pain among patients receiving high-dose therapy. Kaplan et al (57) investigated the use of controlled-release morphine in the management of chronic pain in 44 patients with AIDS. They showed clinically and statistically significant reductions in pain intensity of $50 \%$. Quality of life was fair to good in $80 \%$ of patients. Roth et al (64) evaluated the effectiveness and safety of two dose levels of sustained-released oxycodone compared with placebo in a randomized, double-blind, parallel group trial in 130 patients with moderate to severe pain associated with osteoarthritis. This study showed that sustained-release oxycodone at a dose of $20 \mathrm{mg}$ was significantly better than placebo in reducing pain intensity and interference of pain with mood, sleep, and enjoyment of life. Reder (65) also demonstrated analgesic efficacy of sustained-release oxycodone with a lower rate of discontinuation of therapy, as well as a decrease in pain compared with placebo over the three-month treatment. However, both the studies were of short-term duration. Caldwell et al (66), showed significant improvements in pain intensity and quality of sleep with sustained-release oxycodone compared with placebo among 167 patients with arthritis-associated pain. Hale et al (204) reported that twice-daily sustained-release oxycodone was comparable to four times daily immediate-release oxycodone in terms of efficacy and safety in 57 patients with back pain.

In contrast to the above reports, Maruta and Swanson (161) showed that in 42 patients with musculoskeletal pain in a one month study comparing low dose (30 mg) and high dose (greater than 30 $\mathrm{mg}$ ) oxycodone, significantly lower treatment success rates were observed in the opioid group than the non-opioid group. Turner et al (162) studied 92 patients with musculoskeletal pain and reported greater physical impairment and higher hy- 
pochondriasis and hysteria scores in opioid patients compared to 39 non-opioid patients. Allan et al (59) compared transdermal fentanyl and sustained-release morphine. Pain control was considered good or very good by only $35 \%$ of patients receiving fentanyl compared to $23 \%$ of patients receiving sustained-release morphine.

Thus, considerable controversy continues regarding the use of opioid analgesics for chronic non-cancer pain, specifically as a sole modality of management. Many interventional pain physicians and healthcare professionals are reluctant to support the use of opioid medications for patients with chronic pain as the sole or major treatment because of concerns about long-term efficacy, adverse effects, tolerance and the risk of addiction. Further, studies performed in pain clinics suggest that some patients become psychologically dependent after long-term opioid use $(200,205)$. Some also believe that opioid analgesics contribute to psychological distress, poor treatment outcome, impaired cognition and a fostered reliance on the healthcare system $(33,161$, 162, 205-220). Many physicians, particularly physicians in interventional pain management settings who prescribe opioids for chronic non-cancer pain, worry not only about possible abuse by patients but also about potential liability and sanctions by regulatory agencies $(30,200,219-$ 221). Nonetheless, some clinicians and researchers continue to argue that there is a role for chronic opioid therapy in treating non-cancer pain $(201,222-227)$. Proponents continue to cite the relatively low incidence of abuse and addiction among the pain patients and point out that tolerance does not develop in patients with stable pain pathophysiology (19). According to these advocates, the potential for increased function and improved quality of life significantly outweighs the risk of abuse. Further, some have suggested that chronic opioid therapy may decrease the cost of rehabilitation programs for patients with pain while improving outcome (56). However, the need for studies that address the topic of opioid treatment for chronic non-cancer pain has been noted repeatedly in the pain literature.

A large number of placebo-controlled studies have demonstrated the efficacy of benzodiazepines in the treatment of anxiety disorders, including generalized anxiety disorder, panic disorder, be- havioral treatment of phobias, and other symptoms of psychological distress associated with various medical disorders, including chronic pain (228). However, long-term use of benzodiazepines for treatment of sleep disorders and insomnia may not be appropriate, because benzodiazepines interfere with stage III and IV and REM sleep, and suppress serotonin levels. In addition, as many as $70 \%$ of patients experience some cognitive dysfunction with benzodiazepines. Abrupt withdrawal of benzodiazepines may precipitate a serious drug withdrawal syndrome.

Benzodiazepines have been shown to be effective by objective measures with rapid and dramatic resolution of symptoms of convulsive and spastic disorders. The most common side effects of benzodiazepines in routine clinical use are short-term side effects, along with longterm side effects of abuse and dependency. Use of benzodiazepines has increased steadily from the time of their introduction until the mid to late 1970s. During this period, benzodiazepines have largely displaced the barbiturates. Some contend that despite the wide availability and extensive medical use of benzodiazepines, there has been very little misuse or recreational use of the drugs among adults or youths in the general population (142$163,229,230)$. In contrast, a number of surveys have shown this to be contrary around the world, and specifically in the United States.

\section{TERMINOLOGY}

Concerns about drug abuse complicate every aspect of pain treatment an potentially disrupt a crucial aspect of the practitioner-patient relationship, trust. Continued compulsive overuse of controlled substances by patients, despite harmful consequences, is one of the most potentially destructive behaviors. Thus, healthcare professionals disagree on the use of controlled substances in chronic pain and comorbid psychological disorders. Physicians are understandably reluctant to prescribe opioids and other controlled substances to patients who are at risk for abusing medications and frequently find themselves balancing a patient's need for pain relief with prevention of opioid abuse, as well as the need for self-protection from sanctions by state and federal regulatory agencies (231). Further, there have been patientinitiated lawsuits against physicians for allegedly causing opioid addiction. The laws regarding opioid use in medical patients present issues that are difficult for physicians to balance.

Many clinicians recognize the place for opioids and other controlled substances in the management of chronic pain. Proponents of opioids for chronic pain state that multiple barriers exist to more broad acceptance and use of these efficacious analgesics, which continues to impede their use in the care of patients who could benefit greatly from these drugs. The described barriers are not limited to any one group, nor are they simply due to a lack of knowledge. Proponents note that failure to use indicated opioid results from faulty knowledge, attitudes and practices. The proponents argue that the most common misconceptions among clinicians and the public relate to dependence, addiction and tolerance (232).

There is no agreement between researchers for terms such as drug abuse, psychological dependence, drug dependence, and drug addiction. Often these terms are used interchangeably. Addiction initially meant a habit (30). In fact, in 1957, the World Health Organization defined addiction as a state or period of chronic intoxication characterized by an overpowering desire or need (compulsion to continue taking the drug) and to obtain it by any means; tendency to increase the dose; a psychological and generally a physical dependence on the effects of the drug and detrimental effect on the individual and/or society (233). Subsequently, the World Health Organization (WHO) decided to use the word "dependence" as its crucial variable because some individuals could be physically dependent on a drug without exhibiting compulsive use and vice versa. In 1964, the WHO defined drug dependence as a state of psychological or physical dependence, or both, arising in a person following administration of a drug on a periodic or continuous basis (233).

The Diagnostic and Statistical Manual-IV (DSM-IV) (234) characterizes substance abuse as a maladaptive pattern of substance use manifested by recurrent and significant adverse consequences related to the repeated use of substances. However, neither the World Health Organization nor DSM-IV mentioned the word addiction. Some have argued that traditional definitions presented in the DSM-IV do not apply to patients taking 
opioids for chronic pain $(231,235)$. Robinson et al (231) concluded that most patients on opioids developed tolerance to the opioid and thus, undermedicated for their pain, demonstrate drug-seeking behaviors. They also added that such patients may not be diagnosable according to the same criteria based on non-pain populations (236).

\section{Physical Dependence}

Physical dependence is a physical or pharmacological phenomenon characterized by an abstinence syndrome upon abrupt drug discontinuation, substantial dose reduction or administration of an antagonist. Physical dependence is believed to be nearly universal among patients receiving continuous opioid therapy for a week or more. Dependence occurs not only with opioids, benzodiazepines, sedative-hypnotics, but also with many common medications such as glucocorticoids and some common antihypertensives. Just as with latter drugs, opioids and other controlled substances can be discontinued in dependent patients without withdrawal difficulties by simply tapering them over about a week (232). However, proponents believe that while chronic pain patients often are dependent on their medications, it is not a clinical problem (232). The term "drug dependence" denotes a psychological dependence on a given drug, on a continuum with the addiction.

\section{Addiction}

Addiction is a very different psychological phenomenon that is characterized by loss of control over drug use and compulsive use of the drug despite harm from that use. However, numerous definitions of addiction exist and occasionally drug dependence and addiction are interchanged. Proponents also argue that many of the published conclusions about risk of addiction to opioids are based on studies of addicts (232). Thus, their response to drugs is not relevant to patients in pain who are apt to be physically dependent, not addicted. Proponents also state that addicts normally exhibit profound drug-seeking behavior. However, patients on opioids for chronic pain may exhibit drug-seeking behavior that is not necessarily indicative of abuse or addiction (232). Weisman and Haddox (237) coined the term "pseudoaddiction" as a condition in which a patient is an ap- propriate candidate for an opioid but the drug is not available in sufficient dose to allow the patient to function adequately and maintain a reasonable lifestyle. The patient is relatively underdosed, and as such exhibits drug-seeking behavior. Thus, pseudoaddiction is a recognized condition associated with appropriate drug-seeking behavior for the purpose of comfort, not abuse $(232,237)$. In 1997 , the American Society of Addiction Medicine published a public policy statement recognizing the phenomenon of pseudoaddiction (238). However, validity of the definition and its legitimate existence has been questioned.

McLellan et al (28) examined evidence showing that drug dependence is a chronic medical illness. A literature review comparing the diagnosis, heritability, etiology, pathophysiology and response to treatments of drug dependence versus Type II diabetes mellitus, hypertension, and asthma, showed that genetic heritability, personal choice, and environmental factors are comparably involved in the etiology and course of all these disorders. McLellan et al (28) described that drug dependence produces significant and lasting changes in brain chemistry and function. Further, the idea of pseudoaddiction was based on one cancer patient's experience in a hospital setting who was treated for acute pain. Thus, its relevance in chronic pain in an outpatient setting continues to be uncertain. Even though pseudoaddiction may exist, recent experience of several authors indicates that when abuse behaviors are seen in chronic pain patients, abuse is more likely than pseudoaddiction $(1-3,76,78,79)$. Chabal et al (1) cautioned against the dangers of medicalization of the unproven concept of pseudoaddiction in chronic pain.

\section{Tolerance}

Tolerance to different effects of opioids is variable. These are three-fold and distinct with tolerance to centrally mediated effects of respiratory and CNS depression, tolerance to impairment of judgment and psychomotor function, and tolerance to constipation which does not occur $(239,240)$. In the absence of disease progression, tolerance to analgesic effects of opioids is probably rare, based on experience using opioids in the treatment of cancer pain.

The development of tolerance may have several causes. Some drugs in- duce their own metabolism with repeated exposure, a phenomenon commonly seen with barbiturates. Exposure to other drugs over extended periods may result in changes in receptor density or in signal transduction/receptor linked second messenger systems reducing effectiveness of the drug $(241,242)$. This is one of the mechanisms by which opioid tolerance develops. It is also thought that tolerance to opioids may be associated with NMDA receptor activation, and that the use of NMDA receptor antagonists in conjunction with opioids may delay or reduce the development of tolerance (243). Other agents such as nimodipine, a dihydropyridine calcium channel blocker, may also delay the onset of opioid tolerance in certain individuals. Nimodipine $120 \mathrm{mg}$ daily in divided doses may reduce opioid dose escalation and opioid requirements in cancer pain patients (244).

The term cross-tolerance describes a commonly encountered problem with clinical use of opiates, where higher doses of opioids are required, as compared with those needed in opioid-naïve individuals, even after switching from the opioid they have been chronically using to an alternate opioid formulation (241). However, there may not be complete cross-tolerance among all opioids, and therefore, physicians should factor in a dose reduction when converting a patient from one opioid to another.

\section{General Principles of Controlled SUBSTANCE USAGE}

In interventional pain management, patients may receive not only opioid analgesics, but also other controlled or noncontrolled drugs. Further, patients may be receiving controlled substances as an adjunct to interventional techniques, as well as to manage comorbid psychiatric and psychological disorders. Thus, the effectiveness studies published may not apply in the majority of the cases to interventional pain management. Indeed, controlled substances may be prescribed at lower doses, particularly opioid analgesics to maintain functional status in conjunction with interventional techniques. It has also been shown that interventional techniques reduce psychological distress significantly once the pain improves. Thus, the requirement for adjuvant drugs may be reduced more likely than not (245249). Hence, interventional pain physicians probably should not compare pa- 
tients in their settings undergoing interventional techniques with others receiving drug therapy as mainstay. Monotherapy, particularly with opioids may be appropriate for only a small subgroup of those with chronic pain. Anti-depressants may be prescribed for co-analgesia also, however, anxiolytics and muscle relaxants with potential for dependency should be prescribed with caution with appropriate documentation of psychological distress. Anxiolytics should not be prescribed without a psychological evaluation, either by the treating physician, a psychologist, or psychiatrist.

\section{Patient Selection}

Opioids for the management of chronic pain are not a panacea. They are appropriate only in well-selected patients. Although a majority of patients seeking help suffer from genuine chronic pain, and do not abuse drugs, a minority of patients may be focused on controlled substances rather than pain relief. Differentiating these patients from those suffering from pain is crucial. This task is daunting because there are no objective tools to identify if a given patient has pain and if so how much pain. Physicians treating chronic pain therefore have to rely on subjective reports of the patients to evaluate pain levels. History, physical examination and laboratory and radiologic studies, although useful, unfortunately do not always guide us in accurately distinguishing patients who are suffering in pain from those who are abusing drugs. Most prescription drug abuse is a consequence of prescriptions written by physicians and only a small percentage from prescription fraud, such as prescription alteration or stolen prescriptions. Prescription controlled substance abuse would be almost nonexistent if these drugs were not prescribed. This does not mean that opioids or other controlled substances should not be prescribed for chronic pain of noncancer origin. It signifies that the physicians should be more skilled in distinguish patients suffering from chronic pain from those who are seeking drugs. It is critical to strike a balance between underprescribing and over-prescribing.

\section{Controlled Substance Use Agreement}

A controlled substance agreement should address the abuse issues and encourage patients to assume responsibility for violating the agreement. Physicians should be aware that prescription drug abuse may result despite their best efforts to prevent it. Monitoring of abuse behaviors of patients may be helpful. Abuse ranges from simple misuse to serious addiction. If misuse is ignored, it can potentially lead to addiction. Physicians treating pain usually are not trained to diagnose and treat addiction but they must be able to detect abuse. Abuse is more common than frank addiction in this patient population and hence, detecting abuse behaviors takes precedence over detecting addiction.

\section{Monitoring for Abuse}

It is disheartening and disrupting to interventional pain management physicians to admit a drug abuser or addict to their practices, and it is disruptive to the practice, patient-physician relationship, and insurance carrier. The national drive to eliminate under-treatment of pain and relieve suffering of patients has given drug abusers and addicts an opportunity to enter interventional pain management practices. Even though there are numerous profiles of abusers and addicts, it is a difficult task for an interventional pain physician to identify each and every potential drug abuser. Thus, currently, there are no completely reliable means to distinguish patients who abuse prescribed controlled drugs from those who do not.

\section{Identification of a Patient with a Potential for Abuse}

Because pain is subjective and there are marked inter-individual pain thresholds, it is difficult for clinicians to quantify pain. Unfortunately, history, physical examination, and laboratory investigations are not always helpful in determining whether a patient is in pain, let alone quantifying the pain. This makes it difficult to identify a small, but important number of potential drug abusers who present to the physician complaining of pain. Patient selection is key for successful opioid therapy. Consequently, to a great extent, appropriate patient selection is dependent on screening for abuse and addiction.

There are two challenges facing the physician when attempting to identify patients abusing drugs. . The first challenge is the definition of what is meant by addiction. As described above, traditional DSM III, IIIR, and IV criteria for addiction (some of which are physical depen- dence, withdrawal symptoms, tolerance) do not appear to apply to the chronic pain patient population because most of these patients unjustifiably meet their criteria for addiction (250).

Unlike addiction, abuse can be easily defined from behavioral criteria. Abuse in this setting includes the following:

1. Using opioids for psychological effects and not for pain relief

2. Using opioids or other controlled substance concurrently with illicit drugs

3. Using illegal means to obtain opioids or other controlled substances

4. Deceptive practices to obtain more opioids or other controlled substances

5. Selling controlled substances

6. Using opioids while abusing other psychoactive drugs and/or alcohol

7. Repeatedly taking controlled substances as not intended by the physician

8. Addiction (psychological dependency)

Detection of abuse behaviors takes precedence over detection of addiction (251) because of the following reasons:

1. Abuse is more prevalent than frank addiction (252)

2. Abuse behaviors can easily be identified by physicians, even though physicians treating pain may not be qualified to a diagnosis and treat addiction.

3. Addiction may be prevented, if abuse is recognized and treated in the early course of management.

The second challenge is identification of an abuser. Some available tools may assist a physician to detect a prescription drug abuser. They include:

1. Urine drug screens

2. Screening questionnaire

3. Controlled substance monitoring programs

4. Pill counts

\section{URINe Drug SCReens (UDS)}

Drug screens are very useful to detect drug abuse (253). UDS have become a standard in the addiction treatment community (254), and there is evidence that UDS are useful in this arena (255). It is henceforth logical to extend UDS to the arena of prescription opioid abuse and chronic pain, especially when it has been shown that chronic pain pa- 
tients' self report of drug use is frequently unreliable (256). Katz (253) and Belgrade (257) have shown that UDS are superior than monitoring for abuse behaviors in these patients. Currently, UDS are superior to blood, hair, saliva and sweat drug screens in this setting.

The first and critical feature of the drug screen is the surprise element. Patients should not be aware that drug screens will be done on a particular visit.

The second important prerequisite is the predrug screen questionnaire. It is critical that these questions are posed prior to informing patients that UDS will be done. In the questionnaire, the patients are asked:

1. If they are taking their medications regularly (most of the chronic pain patients usually take controlled substances on a regular basis) and the time and the date of the last dose,

2. If they use marijuana or other illicit drugs,

3. If they take opioids from other physicians or sources.

Thirdly, a patient should not be accompanied by anyone when providing the specimen. Lastly, precautions against tampering must be taken.

The physician preferably uses one laboratory and understands laboratory tests. On every patient, usually 2 tests are done.

\section{Drug Screen-9}

The first test is the DS-9 test (drug screen-9), which is a "screening test." It provides information on 9 controlled substances: opioids, methadone, propoxyphene, marijuana, benzodiazepines, cocaine, amphetamines, barbiturates, and phencyclidine. In the opioids category, codeine, morphine, oxycodone, hydrocodone, and hydromorphone are identified. The test will only report as positive or negative for opioids (not individual drugs), except for methadone and propoxyphene. A cutoff of $300 \mathrm{ng} / \mathrm{mL}$ for opioids, methadone, and propoxyphene are used. Lower cutoff limits may be used to enhance sensitivity.

Measurement of urinary specific gravity, urinary creatinine and $\mathrm{PH}$ must be added to DS-9. DS-9 test can be done by either the EMIT assay or the FPIA (fluorescent polarization immuno assay).

A patient is considered to have an ab- normal DS-9 with any of the following:

1. It is positive for any illicit drug

2. If the prescribed opioids or methadone or propoxyphene are negative despite the patient reporting their regular and recent use in the predrug screen questionnaire.

3. Presence of opioids which are not prescribed. For example, if the patient is on methadone and the DS9 is positive for propoxyphene.

4. If the urine specific gravity and urinary creatinine are below normal limits (it implies that the patient has diluted the urine specimen), an abnormal $\mathrm{pH}$ indicates a probable adulterated specimen.

5. Variation in urine temperature implies tampering. The urine temperature must be between $90^{\circ} \mathrm{F}$ and $100^{\circ} \mathrm{F}$ when measured within 4 minutes of collection.

\section{OPGCMS}

The second test required along with DS- 9 is the OPGCMS test (opiates by gas chromatography mass spectroscopy), which is a "confirmatory" test. This provides information on codeine, morphine, oxycodone, hydrocodone, and hydromorphone individually and specifically unlike the DS-9 test. OPGCMS is the gold standard for confirmation of opioids. The opioids in OPGCMS are cut off at $150 \mathrm{ng} /$ $\mathrm{mL}$. If only a DS-9 is used and if the patient is on codeine, morphine, oxycodone, hydrocodone, or hydromorphone, it will report positive for opioids, but it cannot specifically identify them. For example, if a patient is taking OxyContin ${ }^{\circledR}, \mathrm{DS}$ 9 will report positive for opioids but cannot determine which of the above 5 opioids are present. The OPGCMS will report positive for oxycodone and negative for the other 4 opioids. This is vital because if the patient is taking hydrocodone or other opioids from other physician or other sources, the OPGCMS test would be positive for other opioids. Thus, if only the DS-9 test was performed, it would be positive for opioids and the testing would provide appropriate results, even though he/she is taking other opioids. OPGCMS test is considered abnormal under the following circumstances:

1. The patient is taking morphine, codeine, oxycodone, hydrocodone, or hydromorphone and the drug is not confirmed on the test.
2. The test identifies one of the above opioids when the patient has not been prescribed that opioid.

However, physicians should exercise caution when interpreting the results of OPGCMS due to the following inherent issues:

1. Hydrocodone is metabolized to hydromorphone, therefore, if a patient is taking only hydrocodone, the OPGCMS can potentially report both hydrocodone and hydromorphone and the patient should not be labeled as an abuser. Conversely, hydromorphone is not metabolized to hydrocodone and therefore, if the patient is on hydromorphone, then hydrocodone should not be positive. Another source of confusion may result from the fact that codeine is metabolized to morphine, and morphine may be detected in a urine sample from a patient taking only codeine.

2. Sometimes opioids are positive in the DS-9 screen but negative for morphine, codeine, oxycodone, hydrocodone, and hydromorphone in the OPGCMS. This discrepancy currently cannot be explained. Hence, this should not be considered as an indication of drug abuse.

3. Even though OPGCMS is considered a "gold standard", poppy seeds can cause false positive results for morphine and codeine.

4. Both DS-9 and OPGCMS do not test for fentanyl and meperidine. The lab needs to order special tests to detect these opioids. The test for fentanyl must be very sensitive (cutoff $<150$ $\mathrm{ng} / \mathrm{mL}$ ) because lower equipotent doses of fentanyl are used in lieu of other opioids.

5. It is also difficult to detect heroin abuse using these tests. These tests (DS-9 and OPGCMS) pick up 6acetyl morphine (6 AM), which is a specific metabolite of heroin, but this is reported as positive for morphine. So if the OPGCMS is positive for morphine, the physician should check for $6 \mathrm{AM}$ to confirm heroin use. However, 6 AM has a very short half-life of 45 minutes, and is not usually detected.

6. If the patient is on low opioid doses, it may not be detected in OPGCMS. The lab may be able to provide 
information on detectability of the drug below reporting levels.

\section{Rapid Drug Screening}

A rapid, inexpensive, in-office urine testing may be performed by utilizing a one-step multi-drug screen test card with integrated E-Z split key ${ }^{\mathrm{TM}}$ cup. Thus, onestep drug screen test can be performed without using a specific instrument or apparatus inexpensively ( $\$ 6.00$ per test) to test presence of illicit drugs. The test utilizes a monoclonal antibody to selectively detect elevated levels of specific drugs in urine. This is an immunoassay based on the principle of competitive binding. Drugs which may be present in the urine specimen compete against their respective drug conjugate for the binding site on their specific antibody.

Table 4 shows the test calibrator and cut-off levels for various drugs detected in the urine.

All the precautions in collection of the urine specimen and performance of the test should be followed.

If a patient is unable to give a urine sample, they should have 40 ounces of fluid over a 4 -hour period.

In spite of the above limitations, UDS are currently the best test for detecting abuse. However, not all abusers may show abnormal UDS.

\section{SCREENING QUESTIONNAIRES}

Many questionnaires exist in the psychiatric literature, but they are designed specifically for alcohol and illicit drug abuse and not for prescription controlled substance abuse (236). Additionally, they rely on subjective responses of patients and abusers may provide false answers, probably for fear of loss of controlled substance prescriptions.

Currently there are only two screening tools that exist which are specifically designed to detect prescription opioid abuse. The screening tool by Atluri and Sudarshan (2) is based on objective criteria. Based on preliminary data which was a retrospective case control study, this tool is probably capable of identifying patients with high risk of abuse. External validation with prospective studies is however required. The second tool was developed by Compton et al (236) and validated by a prospective study. This is based on subjective reporting by the patients. This tool also lacks external validation. If needed, these two screening tools either singularly or together can be useful in guiding opioid management $(2,236)$.

\section{GUIDELINES}

Guidelines for prescribing controlled substances must require a comprehensive evaluation (physical and psychological), appropriate documentation at regular intervals to assess the efficacy of therapy, with specific evaluation of the impact on functional status, degree of pain relief, identification and treatment of undesirable side effects and monitoring for abuse behaviors. In addition, there must be adherence to a controlled substance agreement and with regulatory guidelines promulgated by various agencies. Fig. 6 shows an algorithmic approach to patient evaluation and management.

Table 4. Cut-off levels for various drugs detected by urine analysis by Rapid Drug Screening

\begin{tabular}{|l|l|c|}
\hline \multicolumn{1}{|c}{ Rapid Drug Screening } & Calibrator & Cut-off \\
\hline Test & D-Amphetamine & $1,000 \mathrm{ng} / \mathrm{mL}$ \\
\hline Amphetamine (AMP) & Secobarbital & $300 \mathrm{ng} / \mathrm{ML}$ \\
\hline Barbiturates(BAR) & Oxazepam & $300 \mathrm{ng} / \mathrm{ML}$ \\
\hline Benzodiazepines (BZO) & Benzoylecgonine & $300 \mathrm{ng} / \mathrm{ML}$ \\
\hline Cocaine (COC) & 11 -nor- $\triangle 9$-THC-9 $\mathrm{COOH}$ & $50 \mathrm{ng} / \mathrm{ML}$ \\
\hline Marijuana (THC) & Methadone & $300 \mathrm{ng} / \mathrm{ML}$ \\
\hline Methadone (MTD) & D-Methamphetmaine & $1,000 \mathrm{ng} / \mathrm{ML}$ \\
\hline Methamphetamine (MAMP) & D, L Methylenedioxymethamphetamine & $500 \mathrm{ng} / \mathrm{ML}$ \\
\hline $\begin{array}{l}\text { Methylenedioxymethamphetamine } \\
\text { (MDMA) }\end{array}$ & Morphine & $300 \mathrm{ng} / \mathrm{ML}$ \\
\hline Morphine (MOP 300 or OPI 300) & Morphine & $2,000 \mathrm{ng} / \mathrm{ML}$ \\
\hline Opiates (OPI 2000) & Phencyclidine & $25 \mathrm{ng} / \mathrm{ML}$ \\
\hline Phencyclidine (PCP) & Nortriptyline & $1,000 \mathrm{ng} / \mathrm{ML}$ \\
\hline Tricyclic (TCA) & & \\
\hline
\end{tabular}

\section{Evaluation of the Patient}

Appropriate history, physical examination, and medical decision-making based on the initial evaluation of a patient's presenting symptoms are essential. The guidelines of the Centers for Medicare and Medicaid Services (CMS) provide various criteria for five levels of services (258). The three crucial components of evaluation and management services are: history, physical examination, and medical decision-making. Other components include counseling, coordination of care, nature of presenting problem and time required for face-to-face evaluation. While there are numerous techniques to evaluate a chronic pain patient, which vary from physician to physician, institution to institution and textbook to textbook, following the guidelines established by CMS will assist a physician in performing a comprehensive and complete evaluation complying with regulations.

\section{History}

The history includes the chief complaint, history of the present illness, review of systems, and past, family, and/or social history.

History of the present illness is a chronological description of the development of a patient's present illness from the first sign and/or symptom. It includes multiple elements; location; quality, severity, duration, timing, context, modifying factors, and associated signs and symptoms.

Review of systems is an inventory of body systems obtained through a series of questions seeking to identify signs and/or symptoms that the patient may be experiencing or has experienced.

Past, family, and/or social history is crucial in chronic pain patients seeking care with controlled substances. It consists of a review of the past history of the patient, including past experiences, illnesses, operations, injuries, and treatment; family history, including a review of medical events in the patient's family, hereditary diseases, and other factors; and social history appropriate for age reflecting past and current activities. Past history in interventional pain management includes history of past pain problems, motor vehicle, occupational, or non-occupational injuries; history of various pain problems; disorders such as arthritis, fibromyalgia, systemic lupus erythematosus; drug dependency, alcoholism, or drug abuse; 
and psychological disorders such as depression, anxiety, schizophrenia, and suicidal tendencies, etc.

Family history is also crucial. This should include not only the history of different pain problems, including degenerative disorders, but also should include familial disorders, drug or chemical dependency, alcoholism, or drug abuse and psychological disorders such as depression, anxiety, schizophrenia, and suicidal tendencies, etc., specifically in first degree relatives $(11,141,143)$.

Social history is also of crucial importance in administering controlled substances, including environmental information, education, marital status, children, habits, hobbies, occupational history, family support system, and recreational drug usage.

Some of the aspects specific in controlled substance abuse and chronic pain include evaluation of effect of pain on physical and psychological function. Further, the medical record should document the presence of one or more recognized medical indication(s) for the use of controlled substance $(141,143)$.

\section{Physical Examination}

Physical examination in interventional pain management involves general, musculoskeletal, and neurological examinations. Examination of other systems, specifically cardiovascular, lymphatic, skin, eyes and cranial nerves is recommended based on the presenting symptomatology.

\section{Medical Decision Making}

Medical decision making refers to the complexity of establishing a diagnosis and/or selecting a management option, including providing controlled substances to a patient, and is measured by three components: diagnosis/management op- tions with a number of possible differential diagnoses and/or the number of management options; review of records/ investigations, with number and/or complexity of medical records, diagnostic tests, and other information that must be obtained, reviewed, and analyzed; and risks of significant complications, morbidity and mortality, as well as comorbidities associated with the patient's presenting problem(s), the diagnostic procedures, and/or the possible management options.

\section{Psychological Evaluation}

Psychological evaluation is an extension of the evaluation process similar to the laboratory evaluation, imaging techniques, electromyography and nerve conduction studies.

By definition, pain is a subjective description of the patient's perception of actual or potential tissue damage. The

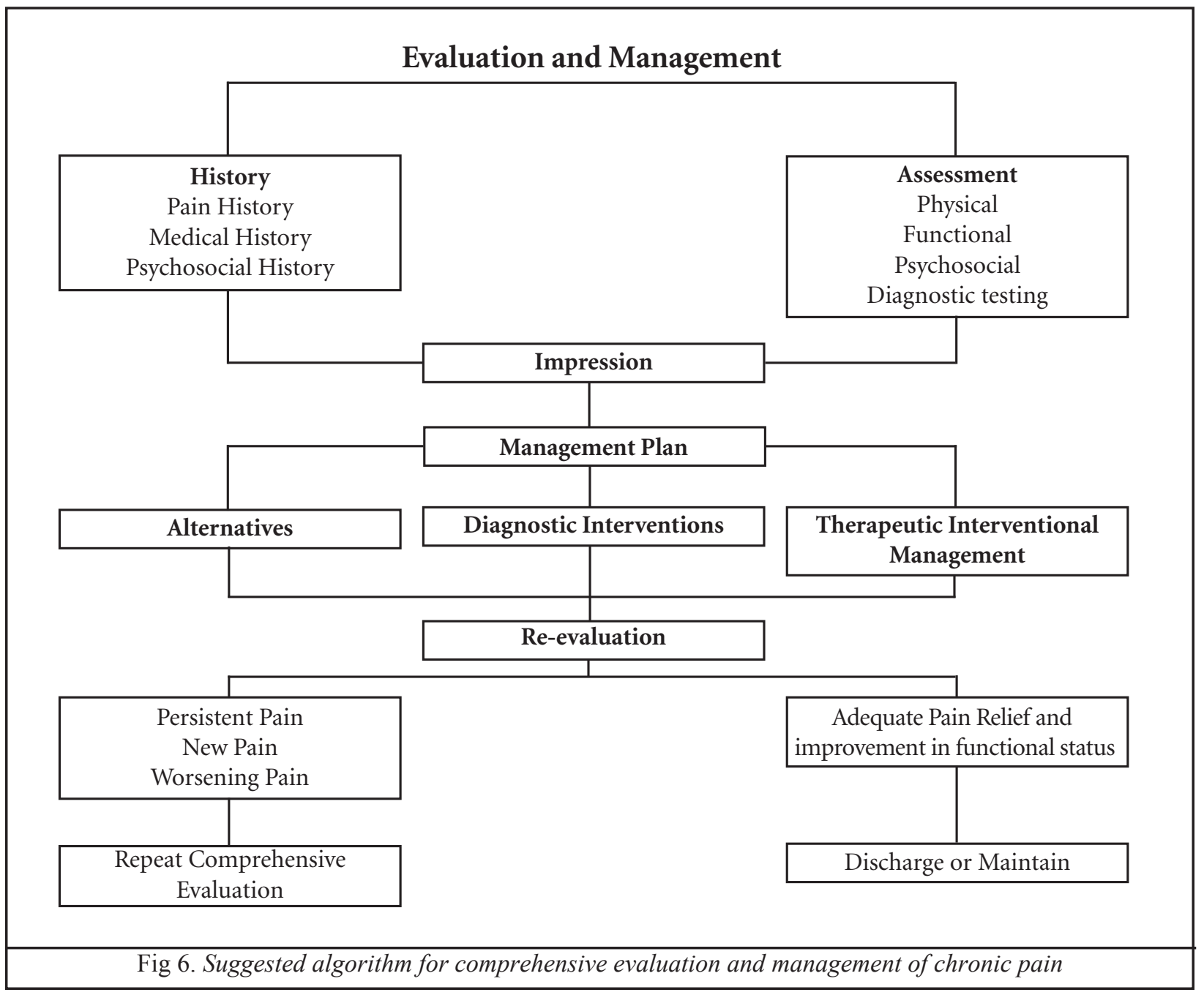

Pain Physician Vol. 6, No. 3, 2003 
distinction between pain and suffering should be established $(141,143)$. A patient may suffer due to pain, but may have other reasons for suffering as well. The assessment of a patient's overall condition should be made at the initial evaluation and thereafter frequently. It is the goal of the physician to assist in the relief of suffering, no matter the cause. Financial, emotional, mental, physical, and spiritual factors may contribute to the patient's suffering. Relief of the underlying reasons for suffering, as well as the pain, will lead to optimal treatment and utilization of controlled substances $(141,143)$.

Prior to embarking on a regimen of controlled drugs, the physician must determine, through actual clinical trial or through patient records and history that non-addictive medication regimens and/ or interventional techniques have been inadequate or are unacceptable for solid, clinical reasons. If this information is not available entirely through the patient, a family conference may be helpful to evaluate the patient's integrity. At the same time, extensive drug utilization history of the patient must be documented through previous medical records, state drug monitoring programs, and multiple other avenues.

\section{Treatment Plan}

A written treatment plan should document objectives that will be used to evaluate treatment success, including pain relief and improved physical and psychosocial function, and should indicate if additional diagnostic tests, consultations, or treatments are planned $(141,143)$. After starting treatment, the physician should adjust the drug therapy to the individual medical needs of each patient, with care. In the continuum of treatment, other modalities, including interventional techniques, rehabilitation, and psychological therapy may be necessary depending on the etiology of pain and the extent to which pain is associated with physical, functional, and psychosocial impairment.

\section{Informed Consent and Controlled Substance Agreement}

At the outset, the physician should discuss the risks and benefits of the use of controlled substances with the patient or surrogate, including the risk of tolerance and drug dependence $(141,143)$. It is advisable to employ the use of a written agreement between physician and patient outlining patient responsibilities. Agreements are mandatory, specifically, if the patient is determined to be at high risk for medication abuse or have a history of substance abuse $(141,143)$. Mandatory items of a controlled substance agreement between a physician and patient include:

1. One prescribing doctor and one designated pharmacy.

2. Urine/serum drug screening when requested.

3. No early refills and no medications called in. If medications are lost or stolen, then a police report could be required before considering additional prescriptions.

The reasons for which drug therapy may be discontinued, such as violation of a documented doctor/patient agreement. Additional items to be included in an agreement are listed in Table 5.

\section{Periodic Review}

At reasonable intervals depending on specific circumstances of a given patient, the physician should review the course of treatment and any new information about the etiology of the pain $(141,143)$. Continuation or modification of therapy should depend on the physician's evaluation of progress towards stated treatment goals, such as a reduction in a patient's pain scores and improved physical and/or psychosocial function (i.e., ability to work, need of healthcare resources, activities of daily living, and quality of social life) $(141,143)$. If treatment goals are not being achieved despite medication adjustments, the physician should reevaluate the appropriateness of continued treatment with the current medications. The physician should monitor patient compliance in medication usage and related treatment plans.

\section{Consultation}

Physicians should be willing to refer a patient as clinically indicated for additional evaluation to achieve treatment objectives. Special attention should be given to those patients who are at risk of misusing their medications and those whose living arrangements create a risk for medication misuse or diversion (141). The management of patients with a history of substance abuse or with a coexisting psychiatric disorder may require extra care, monitoring, documentation, and consultation with or referral to an expert in the man- agement of such patients.

\section{Medical Records}

The physician should keep accurate and complete medical records which include all aspects of interventional pain management and medical care. These comprise, but are not limited to:

- The medical history and physical examination

- Diagnostic, therapeutic, and laboratory results

- Evaluations and consultations

- Treatment objectives

- Discussion of risks, benefits, and limitations of treatments

- Details of different treatments, medications, including date, type, dosage, and quantity prescribed

- Instructions to the patient

- Periodic reviews of outcomes

Records should remain current and be maintained in an accessible manner and readily available for review, not only for the physician and other members of the practice, but also the authorities.

To be in compliance with controlled substance laws and regulations required to prescribe, dispense, or administer controlled substances, the physician must have an active license in the state and comply with applicable federal and state regulations. Various boards have published regulations and recommendations for prescribing controlled substances. Physicians are advised to refer to these regulations for their respective state.

Physicians, under all circumstances, except for unavoidable emergencies, should not prescribe scheduled drugs for themselves, immediate family, or staff.

A suggested algorithm for comprehensive evaluation and management of chronic pain in the interventional pain management settings is shown in Fig. 6 . In summary, the following criteria should be considered carefully in providing controlled substances:

1. Complete initial evaluation, including history and physical examination

2. Psychological evaluation

3. Physiological and functional assessment, as necessary and feasible

4. Definition of indications and medical necessity:

- Pain of moderate-to-severe degree 
Table 5. A Sample Controlled Substance Agreement

We are committed to doing all we can to treat your chronic pain condition. In some cases, opioids and other controlled substances are used as a therapeutic option in the management of chronic pain and related conditions all of which are strictly regulated by both state and federal agencies. This agreement is a tool to protect both you and the physician by establishing guidelines, within the laws, for proper controlled substance use.

1. All controlled substances have a potential for dependency and abuse.

2. All controlled substances must come from the physician whose signature appears below or, during his absence, by the covering physician, unless specific authorization is obtained for an exception.

3. All controlled substances must be obtained at the same pharmacy, where possible. Should the need arise to change pharmacies our office must be informed. The pharmacy that you have selected is:

phone:

4. The prescribing physician has permission to discuss all diagnostic and treatment details with dispensing pharmacists or other professionals who provide your health care for purpose of maintaining accountability.

5. You may not share, sell, or otherwise permit others including spouse or family members to have access to these medications.

6. Unannounced urine or serum toxicology screens may be requested, and your cooperation is required. Presence of unauthorized substances may result in your discharge from the facility.

7. I will not consume excessive amounts of alcohol in conjunction with narcotics, nor will I use, purchase, or otherwise obtain any illegal drugs.

8. Medications may not be replaced if they are lost, stolen, get wet, are destroyed, left on an airplane, etc. If your medication has been stolen it will not be replaced unless explicit proof is provided with direct evidence from authorities. A report narrating what you told is not enough.

9. If the responsible legal authorities have questions concerning your treatment, as might occur, for example, if you were obtaining medications at several pharmacies, all confidentiality is waived and these authorities may be given full access to our records of controlled substances administration.

10.Early refills will not be given. Renewals are based upon keeping scheduled appointments. Please do not phone for prescriptions after hours or on weekends.

11. In the event you are arrested or incarcerated related to legal or illegal drugs, refills on controlled substances will not be given.

12.It is understood that failure to adhere to these policies may result in cessation of therapy with controlled substance prescribing by this physician.

13. You affirm that you have full right and power to sign and be bound by this agreement, and that you have read, understand, and accept all of its terms.

Patient's full name

Patient's signature

Date

Physician's signature

Date 
- Suspected organic problem.

- Failure to respond to noncontrolled substances, adjuvant agents, physical therapy, and interventional techniques

- For patients with interventional techniques as primary modality and controlled substance drugs as a second line treatment.

- Responsiveness to prior interventions with improvement in physical and functional status for continued management, with or without interventions, must be documented

- For non-opioid controlled substances, appropriate documentation of psychological disorders should be maintained.

- Continued controlled substance prescription requires;

- Reduction in pain

- Improvement in functional status

- Lack of evidence of drug abuse

5. Adherence to controlled substance agreement with patients understanding the risks and benefits of controlled substances and the policy and regulations of the practitioner, including controlled substances being prescribed by only one practitioner and being obtained from only one pharmacy.

6. Monitoring for drug abuse or diversion should be routine and if confirmed, referral to rehabilitation centers may be made, with termination of prescriptions of controlled substances.

\section{SUMMARY}

Controlled substances, particularly opioids, have an important role in chronic pain management, however, their use requires intensive monitoring. When prescribing opioids for chronic pain, the practitioner should realize that there is very little evidence that opioids promote enhanced functional lifestyle, return to work capacity, or other measurable functional enhancements. In fact, opioids for chronic nonmalignant pain carry a risk, and this risk-reward benefit should be weighed carefully. The patient-physician relationship is based on trust and the patient must have an understanding that these drugs have risks, and agree to the guidelines presented by the physician.
- Thorough evaluation of the pain complaint must be done, including appropriate history and physical examination. Additional tests must be ordered and reviewed as needed.

- Some patients may benefit from psychological clearance prior to embarking upon opioid therapy.

- An attempt to diagnose the condition causing pain and treating the cause must be made, keeping in mind that it is always not possible to eliminate the source of chronic pain.

- Opioids generally should be considered a treatment of last resort. Every attempt must be made to use non-opioid modalities to relieve pain in conjunction, or prior to, using opioids. These modalities include interventional therapy, physical therapy, and rehabilitation, psychological therapy, and nonopioid medications. Referrals to appropriate physicians must be made if necessary to realize the above objective. In some cases, opioids can be used in the initial phase.

- Controlled substance agreements must be made with patients which explain the potential risks and benefits of opioids (including risk of dependency and side effects) and also the policies and the regulations of the physician.

- Patients should demonstrate a high level of responsibility and proactive interest in their own health care prior to prescribing opioids or habituating medications.

- An accountability system must be in place for writing and dispensing the prescriptions. It is inappropriate to regularly call in controlled substances to the pharmacy. Documentation in the medical record must be up to date. Providing prescriptions for controlled substances on weekends, holidays, and after hours should be discouraged. Phone prescriptions should not be a common practice, but in unusual situations only. The patient should understand that rescue doses are for extraordinary purposes only, and the patient care agreement should state that if the patient loses his/her medication, or if it is stolen or misplaced, that it will not be replaced under any circumstances. Patients that obtain a police report stating that their medications were stolen, simply fill out brief paperwork. In general, a lost prescription should not be replaced. A close patient-physician relationship may yield some latitude in this regard, but should be a rare occurrence.

Strategies to avoid diversion include:

- Keeping copies of prescriptions, nonfaxing duplicating prescriptions, and unique prescription pads.

- Controlled substances must be prescribed by only one physician or one group of physicians.

- Long acting opioids are preferable, especially if the pain is constant.

- Improvement of function, along with pain relief, must be the goals of therapy.

- Patients should be evaluated at regular intervals to assess the efficacy of the therapy, to evaluate the impact on functional status, to detect and treat undesirable side effects, and to monitor abuse behaviors.

- Based on individual practice settings, patients may be screened randomly for drug abuse by various means.

- If drug abuse is confirmed, a referral to rehabilitation centers should be made. Each physician should have a policy in place to handle drug abuse, with reference to continued management, with or without controlled substances. Opioids should not be abruptly discontinued even in the face of abuse and must be weaned off to avoid withdrawal. An exception to this occurs when a patient is found to be involved in criminal behavior, such as diversion. In this situation, the patientphysician relationship has been violated, and the physician has no obligation to continue treatment.

- If drug abuse is confirmed, the appropriate regulatory agencies may be notified, based on the apparent seriousness of the situation.

- Most states have guidelines for using controlled substances for chronic pain, specifically opioids, and they should be adhered to.

- In most cases, a zero tolerance policy must be in place. The physician should remember that he/she has no obligation to provide prescription controlled substances to a patient that is inappropriate and has violated the patient-physician 
relationship. However, the physician must maintain meticulous records in order to justify termination of treatment of a patient.

Opioid use should be contraindicated or used with extreme caution if patients show evidence of abuse.

Author Affiliation
Sairam Atluri, MD
Medical Director
Tri-State Pain Management Institute
10160 Meadowknoll Drive
Loveland, Ohio 45140
E-mail: atluri_ps@sprynet.com

Mark V. Boswell, MD, PhD

Chief Division of Pain Medicine Department of Anesthesiology Case Western Reserve University School of Medicine and University Hospitals of Cleveland 11100 Euclid Avenue Cleveland, Ohio, 44106 E-mail: mark.boswell@uhhs.com

\section{Hans C. Hansen, MD \\ Medical Director \\ The Pain Relief Centers, PA \\ 3451 Greystone Place SW \\ Conover, North Carolina 28613 \\ E-mail: hans@hippocrates.org}

\section{Andrea M. Trescot, MD}

Medical Director

The Pain Center

1895 Kingsley Ave, Suite 903

Orange Park, Florida 32073

E-mail: amt57@aol.com

\section{Vijay Singh, MD}

Medical Director

Pain Diagnostic Associates

1601 Roosevelt Road

Niagara, Wisconsin 54151

E-mail vsingh@netnet.net.

\section{Arthur E. Jordan, MD}

Medical Director

Carolina Health Specialist

945 82nd Parkway

Myrtle Beach, South Carolina 29572

E-mail:paindoc@carolinahealth.com

\section{ConcLusion}

Controlled prescription drugs, including opioid analgesics, anxiolytics, stimulants and sedative-hypnotics play a significant and legitimate role in managing chronic pain, anxiety, depression, insomnia, and muscle spasm. However, controversy continues regarding use of controlled substances in pain management. These guidelines detail different aspects of controlled substances, their use, misuse, and proposed guidelines to improve patient treatment and safety.

\section{REFERENCES}

1. Chabal C, Erjavec MK, Jacobson L et al. Prescription opiate abuse in chronic pain patients: Clinical criteria, incidence, and predictors. Clin J Pain 1997; 13:150-155.

2. Atluri S, Sudarshan G. A screening tool to determine the risk of prescription opioid abuse among patients with chronic nonmalignant pain. Pain Physician 2002; 5 : 447-448.

3. Manchikanti L, Brown K, Singh V. National All Schedules Prescription Electronic Reporting Act NASPER: Balancing substance abuse and medical necessity in interventional pain management. Pain Physician 2002; 5:294-319.

4. Hill CS. When will adequate pain treatment be the norm? JAMA 1995; 274:18811882.

5. Dahl JL. Improving the practice of pain management. JAMA 2000; 284:2785.

6. Hoffmann DE. Pain management and palliative care in the era of managed care: Issue for health insurers. J Law, Med \& Ethics 1998; 26:267-289.

7. Cleeland CS, Gonin R, Hatfield AK et al. Pain and its treatment in outpatients with metastatic cancer. N Engl J Med 1994; 330:592-596.

8. Joranson DE, Carrow GM, Ryan KM et al. Pain management and prescription monitoring. J Pain Symptom Manage 2002; 23: 231-238.

9. Portenoy RK. Opioid therapy for chronic nonmalignant pain: Clinicians' perspective. J Law Med Ethics 1996; 24:296-309.

10. Pappagallo M, Heinberg LJ. Ethical issues in the management of chronic nonmalig. nant pain. Semin Neurol 1997; 17:203211.

11. Model Guidelines for the Use of Controlled Substances for the Treatment of Pain. Federation of State Medical Boards of the United States, Inc., May 1998.

12. Glajchen M. Chronic pain: Treatment barriers and strategies for clinical practice. Am Board Fam Pract 2001; 14:211-218.

13. American Pain Society. Chronic Pain in America: Roadblocks to Relief. Available at: http://www.ampainsoc.org.
14. Khouzam HR. Chronic pain and its management in primary care. Southern Med 2000; 93:946-952.

15. Lebovits AH, Florence I, Bathina R et al. Pain knowledge and attitudes of healthcare providers: Practice characteristic differences. Clin J Pain 1997; 13:237-243.

16. Weinstein SM, Laux LF, Thornby II et al. Medical students' attitudes toward pain and the use of opioid analgesics: Implications for changing medical school curriculum. Southern Med / 2000; 93:472-478.

17. Portenoy RK. Opioid therapy for chronic nonmalignant pain: A review of the critical issues. J Pain Symtom Manage 1996; 11:203-217.

18. Passik SD, Weinreb HJ. Managing chronic nonmalignant pain: Overcoming the obstacles to the use of opioids. Adv In Ther 2000; 17:70-83.

19. Porter J, Jick H. Addiction rare in patients treated with narcotics [letter]. N EnglJ Med 1980; 302:123.

20. Promoting pain relief and preventing abuse of pain medications: A critical balancing act. A joint statement from 21 health organizations and the Drug Enforcement Administration. Available at: http://www.ampainsoc.org/advocacy/ pdf/consensus_1.pdf.

21. Foley KM. Opioids and chronic neuropathic pain. N Engl / Med 2003; 348:12791281.

22. Sindrup HJ, Jensen TS. Efficacy of pharmacological treatments of neuropathic pain: an update and effect related to mechanism of drug action. Pain 1999; 83:389400

23. Carver A, Foley K. Facts and an open mind should guide clinical practice. Curr Neurol Neurosci Rep 2001; 1:97-98.

24. Rowbotham MC, Twilling L, Davies PS et al. Oral opioid therapy for chronic peripheral and central neuropathic pain. $N$ Engl J Med 2003; 348:1223-1232.

25. Dellemijn P. Are opioids effective in relieving neuropathic pain? Pain 1999; 80:453462.

26. Attal N, Guirimand F, Brasseur L et al. Effects of IV morphine in central pain: a randomized placebo-controlled study. Neurology 2002; 58:554-563.

27. Drug Enforcement Administration. Physician's manual: An informational outline of the Controlled Substances Act of 1970. Washington, DC: US Department of Justice, 1990.

28. McLellan AT, Lewis DC, O'Brien CP et al. Drug dependence, a chronic medical illness. JAMA 2000; 284:1689-1695.

29. Lewin ICF. Analysis of Prescription Monitoring Programs. Prepared for HoffmanLaRoche by Lewin ICF. Washington DC, April 26, 1991.

30. Fishbain DA, Rosomoff HL, Rosomoff RS Drug abuse, dependence, and addiction in chronic pain patients. Clin J Pain 1992; 8 : 77-85. 
31. Fishbain DA, Cutler RB, Rosomoff HL et al. Validity of self-reported drug use in chronic pain patients. Clin J Pain 1999; 15:184191.

32. Ready LB, Sarkis E, Turner JA. Self-reported vs actual use of medications in chronic pain patients. Pain 1982; 12:285-294.

33. Maruta T, Swanson DW, Finlayson RE. Drug abuse and dependency in patients with chronic pain. Mayo Clin Proc 1979; 54:241-244.

34. Hoffmann NG, Olofsson O, Salen B et al. Prevalence of abuse and dependency in chronic pain patients. Int J Addict 1995; 30:919-927.

35. Jinks MJ, Raschko RR. A profile of alcohol and prescription drug abuse in a highrisk community-based elderly population. DICP 1990; 24:971-975.

36. Turk DC, Okifuji A. What factors affect physicians' decisions to prescribe opioids for chronic noncancer pain patients. Clin J Pain 1997; 13:330-336.

37. Seres JL, Painter JR, newman RI. Multidisciplinary treatment of chronic pain at the North West Pain Center. In: Ng LKY (ed). New approaches to treatment of chronic pain: A review of multidisciplinary pain clinics and pain centers. Bethesda, Maryland: National Institute of Disability, 1981: 41-64. (NIDA monograph; vol 36).

38. Long DM. A comprehensive model for the study and therapy of pain: Johns Hopkins pain research and treatment program. In: $\mathrm{Ng}$ LKY (ed). New approaches to treatment of chronic pain: A review of multidisciplinary pain clinics and pain centers. Bethesda, Maryland: National Institute of Disability, 1981:66-75. (NIDA monograph; vol 36).

39. Finlayson RE, Maruta T, Morse RM et al. Substance dependence and chronic pain: Experience with treatment and follow up results. Pain 1986; 26:175-180.

40. Khatami M, O’Brien C. Chronic pain and narcotic addiction: A multitherapeutic approach - 1. Pilot study. Compr Psychiatry 1979; 20:55-60.

41. Ziesat HA. Drug use and misuse in operant pain patients. Addict Behav 1982; 4: 463-266.

42. Finlayson RE, Maruta T, Morse RE et al. Substance dependence and chronic pain: Profile of 50 patients treated in an alcohol and drug dependence unit. Pain 1986; 26: 167-174.

43. Anthony JC. Drug use and dependence outside medical settings: Recent epidemiological evidence. TEN 2000; 2:54-58.

44. Anthony JC, Warner LA, Kessler RC. Comparative epidemiology of dependence on tobacco, alcohol, controlled substances and inhalants: Basic findings from the $\mathrm{Na}$ tional Comorbidity Survey. Exp Clin Psychopharmacol 1994; 2:244-268.

45. American Medical Association. Curtailing prescription drug abuse while preserving therapeutic use: American Medical Association recommendations for drug con- trol policy. In Wilford BB (ed). Balancing the Response to Prescription Drug Abuse. American Medical Association, Chicago, 1990, pp 273-298.

46. New York State Public Health Council. Breaking down the barriers to effective pain management: Recommendations to improve the assessment and treatment of pain in New York State. Albany, NY: New York State Department of Health, 1998.

47. Alliance of States with Prescription Monitoring Programs. The goals of prescription monitoring. Jamaica Plain, MA: Massachusetts Department of Health, Drug Control Program, 1999. http://www.nascsa.org/ monitoring.htm.

48. Swanson DW, Maruta T, Wolff VA. Ancient pain. Pain 1986; 25:383-387.

49. Benedikt RA, Kolb LC. Preliminary findings on chronic pain and posttraumatic stress disorder. Am J Psychiatry 1986; 143:908910.

50. Langemark M, Olesen J. Drug abuse in migraine patients. Pain 1984; 19:81-86.

51. Granella F, Farina S, Malferrari G et al. Drug abuse in chronic headache: A clinico-epidemiologic study. Cephalalgia 1987; 7:15-19.

52. Joranson DE, Ryan KM, Gilson AM et al. Trends in medical use and abuse of opioid analgesics. JAMA 2000; 283:1710-1714.

53. Drug Enforcement Administration, $\mathrm{Na}$ tional Alliance for Model State Drug Laws. Diversion and abuse of prescription drugs: A closer look at state prescription monitoring programs. Washington, DC: Drug Enforcement Administration, 200o. http://www.deadiversion.usdoj.g ov/pubs/program/prescription_monitor/ index.html).

54. Garcia J, Altman RD. Chronic pain states: Pathophysiology and medical therapy. Semin Arthritis Rheum 1997; 27:1-16.

55. Portenoy RK. Chronic opioid therapy in nonmalignant pain. J Pain Symptom Manage 1990; 5:S46-S62.

56. Zenz M, Strumpf M, Tryba M. Long-term oral opioid therapy in patients with chronic nonmalignant pain. J Pain Symptom Manage 1992; 7:69-77.

57. Kaplan R, Cnoant M, Cundiff D et al. Sus tained-release morphine sulphate in the management of pain associated with acquired immune deficiency syndrome. J Pain Symptom Manage 1996; 12:150-160.

58. Moulin DE, Lezzi A, Amireh R et al. Randomized trial of oral morphine for chronic non-cancer pain. Lancet 1996; 347:143147.

59. Allan L, Hays H, Jensen NH et al. Randomized crossover trial of transdermal fentanyl and sustained release oral morphine for treatment of chronic non-cancer pain. BMJ 2001; 322:1-7.

6o. Niemann T, Madsen LG, Larsen S et al. Opioid treatment of painful chronic pancreatitis. Int J Pancreatol 2000; 27:235 240.
61. Newshan G, Lefkowitz M. Transdermal fentanyl for chronic pain in AIDS: A pilot study. J Pain Symptom Manage 2001; 21: 69-77.

62. Portenoy RK, Sciberras A, Eliot $L$ et al. Steady-state pharmacokinetics comparison of a new, extended-release, oncedaily morphine formulation, Avinza, and a twice-daily controlled-release morphine formulation in patients with chronic moderate-to-severe pain. J Pain Symptom Manage 2002; 23:292-300.

63. Flöter T, Koch EM and the Kap-Cas Study Group. Comparison of two oral morphine formulations for chronic severe pain of malignant and non-malignant origin: Kapanol vs MST®. Clin Drug Invest 1997; 12: 183-191.

64. Roth SH, Fleischmann RM, Burch FX et al. Around-the-clock, controlled-release oxycodone therapy for osteoarthritis-related pain. Placebo-controlled trial and longterm evaluation. Arch Intern Med 2000; 160:853-860.

65. Reder RF. Opioid formulations: Tailoring to the needs in chronic pain. Eur J Pain 2001; 5:109-111.

66. Caldwell JR, Hale ME, Boyd RE et al. Treatment of osteoarthritis pain with controlled release oxycodone or fixed combination oxycodone plus acetaminophen added to nonsteroidal anti-inflammatory drugs: A double blind, randomized, multicenter, placebo controlled trial. I Rheumatol 1999; 26:862-869.

67. 2001 National Household Survey on Drug Abuse (NHSDA). DHHS Publication No. (SMA) 02-3758. Rockville, MD: Department of Health and Human Services; Substance Abuse and Mental Health Services Administration, 2002.

68. Lynskey MT, Heath AC, Bucholz KK et al. Escalation of drug use in early-onset cannabis users vs co-twin controls. JAMA 2003; 289: 427-433.

69. Bachman JG, Johnston LD, O'Malley PM. Explaining recent increases in students' marijuana use: Impacts of perceived risks and disapproval, 1976 through 1996. Am J Public Health 1998; 88:887-892.

70. Sloboda Z. Drug abuse patterns in the United States. IEWG June 1999; 89-107.

71. Epidemiologic Trends in Drug Abuse Advance Report. Community Epidemiology Work Group. National Institutes of Health. National Institute on Drug Abuse. CEWG Publications, Rockville, Maryland, June 2001.

72. The D.A.W.N. Report. Office of Applied Studies, Substance Abuse and Mental Health Services Administration (SAMHSA); Jan 2003.

73. Simoni-Wastila L, Tompkins C. Balancing diversion control and medical necessity: The case of prescription drugs with abuse potential. Substance Use \& Misuse 2001; 36:1275-1296.

74. Batten HL, Prottas JM, Horgan CM et al. Drug Services Research Survey. Phase II 
Final Report. Submitted to the National Institute on Drug Abuse. Institute for Health Policy, Brandeis University, Waltham, MA February 12, 1993.

75. The NHSDA Report. Nonmedical Use of Prescription-Type Drugs among Youths and Young Adults. Office of Applied Studies, Substance Abuse and Mental Health Services Administration (SAMHSA), Jan 2003.

76. Manchikanti L, Pampati V, Damron K et al. Prevalence of opioid abuse in interventional pain medicine practice settings: $A$ randomized clinical evaluation. Pain Physician 2001; 4:358-365.

77. Polatin PB, Kinney RK, Gatchel RJ et al. Psychiatric illness and chronic low back pain: The mind and the spine - which goes first? Spine 1993; 18:66-71.

78. Manchikanti L, Pampati V, Damron K, Beyer C, Barnhill R. Prevalence of illicit drug use in patients without controlled substance abuse in interventional pain management. Pain Physician 2003; 6:173 178.

79. Manchikanti L, Damron K, Beyer C et al. A comparative evaluation of illicit drug use in patients with or without controlled substance abuse in interventional pain management. Pain Physicians 2003; 6: 281285.

80. Manchikanti L. Prevalence of prescription drug abuse and dependency in patients with chronic pain in western Kentucky. J KY Med Assoc 2003; in press.

81. Graziotti PJ, Goucke CR. The use of oral opioids in patients with chronic non-cancer pain. Management strategies. Med J Aust 1997; 167:30-34

82. Fishman SM, Wilsey B, Yang J et al. Adherence monitoring and drug surveillance in chronic opioid therapy. J Pain Symptom Manage 2000; 20:293-307.

83. Hutchinson L, Keenan E, Cheasty $M$ et al. A comparison of attendance for drug misuse to Dublin accident \& emergency departments 1985-1993. Ir Med J 1995; 88: 56-57.

84. Crews JC, Denson DD. Recovery of morphine from a controlled-release preparation. A source of opioid abuse. Cancer 1990; 66:2642-2644.

85. Baumrucker SJ. OxyContin $\AA$, the media, and law enforcement. Am J Hospice Palliat Care 2001; 18:154-156.

86. Spake A. 'Not an appropriate use' Did the makers of OxyContin push too hard? US New world Rep 2001; July 2:26.

87. Hancock CM, Burrow MA. OxyContin use and abuse. Clin J Oncol Nurs 2002; 6:109110.

88. Poklis A. Fentanyl: A review for clinical and analytical toxicologists. Clin Toxicol 1995; 33:439-447.

89. Flannagan LM, Butts JD, Anderson WH. Fentanyl patches left on dead bodies-potential source of drug for abusers. J Forensic Sci 1996; 41:320-321.
90. Arvanitis ML, Satonik RC. Transdermal fentanyl abuse and misuse. J Emerg Med 2002; 20:58-59.

91. DeSio JM, Bacon DR, Peer $\mathrm{G}$ et al. Intravenous abuse of transdermal fentanyl therapy in a chronic pain patients. Anesthesiology 1993; 79:1139-1141.

92. Kramer C, Tawney M. A fatal overdose of transdermally administered fentanyl. J Am Osteopath Assoc 1998; 98:385-386.

93. Gourlay GK. Treatment of cancer pain with transdermal fentanyl. Lancet Oncol 2001; 2:165-172.

94. Bonica JJ. Definitions and taxonomy of pain. In Bonica JJ, Loessor JD, Chapman CR et al (eds). The Management of Pain, Second Edition. Lea \& Febiger, Philadelphia, 1990; Vol. 1: pp 18-27.

95. Elliott AM, Smith BH, Hannaford PC et al. The course of chronic pain in the community: Results of a 4-year follow-up study. Pain 2002; 99:299-307.

96. Yeung SS, Genaidy A, Deddens I et al. Prevalence of musculoskeletal symptoms in single and multiple body regions and effects of perceived risk of injury among manual handling workers. Spine 2002; 27:2166-2172.

97. Verhaak PFM, Kerssens JJ, Dekker J et al. Prevalence of chronic benign pain disorder among adults: A review of the literature. Pain 1998; 77:231-239.

98. Elliott AM, Smith BH, Penny KI et al. The epidemiology of chronic pain in the community. Lancet 1999; 354:1248-1252.

99. Andersson HI, Ejlertsson G, Leden I et al. Chronic pain in a geographically defined general population: Studies of differences in age, gender, social class, and pain localization. Clin J Pain 1993; 9:174-182.

100. Barajas C, Bosch F, Baños J. A pilot survey of pain prevalence in schoolchildren. Pain Clin 2001; 13:95-102.

101. Perquin CW, Hazebroek-Kampschreur AA, Hunfeld JA et al. Chronic pain among children and adolescents: Physician consultation and medication use. Clin J Pain 2000; 16:229-235.

102. Manchikanti L. Epidemiology of low back pain. Pain Physician 2000; 3:167-192.

103. Ferrell BR, Ferrell BA (eds). Pain in the elderly. A report of the task force on pain in the elderly of the international association for the study of pain. IASP Press, Seattle, 1996.

104. Lawrence RC, Helmick CG, Arnett FC. Estimates of the prevalence of arthritis and selected musculoskeletal disorders in the United States. Arthritis Rheum 1998; 41: 778-799.

105. Bressler HB, Keyes WJ, Rochon PA et al. The prevalence of low back pain in the elderly. A systemic review of the literature. Spine 1999; 24:1813-1819.

106. Weiner DK, Herr K, Rudy TE (eds). Persistent pain in older adults. An Interdisciplinary Guide for Treatment. Springer Publishing Company, New York, 2002.
107. Cassidy D, Carroll L, Cotê P: The Saskatchewan Health and Back Pain Survey. The prevalence of low back pain and related disability in Saskatchewan Adults. Spine 1998; 23:1860-1867.

108. Leboeuf-Yde C, Lauritsen JM. The prevalence of low back pain in the literature. A structured review of 26 Nordic studies from 1954 to 1993 . Spine 1995; 20:21122118.

109. Côté DC, Cassidy JD, Carroll L. The Saskatchewan Health and Back Pain Survey. The prevalence of neck pain and related disability in Saskatchewan adults. Spine 1998; 23:1689-1698.

110. Croft PR, Lewis M, Papageorgiou AC et al. Risk factors for neck pain: A longitudinal study in the general population. Pain 2001; 93:317-325.

111. Walker BF. The prevalence of low back pain in Australian adults. A systematic review of the literature from 1966-1998. Asia Pac J Public Health 1999; 11:45-51.

112. Manchikanti L, Staats P, Singh V et al. Evidence-based practice guidelines for interventional techniques in the management of chronic spinal pain. Pain Physician 2003; 6:3-80.

113. Linton SJ, Hellsing AL, Hallden K. A population based study of spinal pain amons 35-45-year old individuals. Spine 1998; 23:1457-1463.

114. Van Den Hoogen HJM, Koes BW, Deville $W$ et al. The prognosis of low back pain in general practice. Spine 1997; 22:15151521.

115. Croft PR, Papageorgiou AC, Thomas E et al. Short-term physical risk factors for new episodes of low back pain. Prospective evidence from the South Manchester Back Pain Study. Spine 1999; 24:15561561.

116. Carey TS, Garrett JM, Jackman A et al. Recurrence and care seeking after acute back pain. Results of a long-term followup study. Medical Care 1999; 37:157-164.

117. Miedema HS, Chorus AMJ, Wevers (WJ et al. Chronicity of back problems during working life. Spine 1998; 23:2021-2029.

118. Thomas E, Silman AJ, Croft PR et al. Predicting who develops chronic low back pain in primary care. A prospective study. Brit Med J 1999; 318:1662-1667.

119. Wahlgren DR, Atkinson JH, Epping-Jordan JE et al. One-year follow up of first onset low back pain. Pain 1997; 73:213-221.

120. Schiottz-Christensen B, Nielsen GL, Hansen VK et al. Long-term prognosis of acute low back pain in patients seen in general practice: A 1-year prospective follow-up study. Fam Pract 1999; 16:223-232.

121. Ferguson SA, Marras WS, Gupta P. Longitudinal quantitative measures of the natural course of low back pain recovery. Spine 2000; 25:1950-1956.

122. Vingård $\mathrm{E}$, Mortimer $\mathrm{M}$, Wiktorin $\mathrm{C}$ et al. Seeking care for low back pain in the general population: A two-year follow-up 
study: Results from the MUSIC-Norrtalje Study. Spine 2002; 27:2159-2165.

123. Waxman R, Tennant A, Helliwell P. A prospective follow up study of low back pain in the community. Spine 2000; 25:20852090.

124. Hallgern RC, Greenman PE, Rechtien JJ. Atrophy of suboccipital muscles in patients with chronic pain: A pilot study. JAm Osteopath Assoc 1994; 12:1032-1039.

125. Hildingsson C, Toolanen G. Outcome after soft-tissue injury of the cervical spine: $A$ prospective study of 93 car accident victims. Acta Orthop Scand 1990; 61:357359.

126. Hodgson S, Grundy M. Whiplash injuries: Their long-term prognosis and its relationship to compensation. Neuro Orthopedics 1989; 7:88-91.

127. Gureje O, Von Korff M, Simon GE et al. Persistent pain and well-being: A World Health Organization Study in Primary Care. JAMA 1998; 280:147-151.

128. Simons DG. Muscular pain syndromes. In Friction JR, Awad EA (eds). Advances in Pain Research and Therapy. LippincottRaven, Philadelphia, 1990, Vol 17.

129. Macfarlane GJ. Fibromyalgia and chronic widespread pain. In epidemiology of pain. Crombie IK, Croft PR, Linton SJ et al (eds), IASP Press, Seattle, 1999, pp 113-124.

130. Melton LJ, Lane AW, Cooper C et al: Prevalence and incidence of vertebral deformities. Osteoporosis Int 1993; 3:113-119.

131. Harden RN. A clinical approach to complex regional pain syndrome. Clin J Pain (Suppl) 2000; 16:S26-32.

132. CDC. Prevalence of disabilities and associated health conditions among adults United States, 1999. MMWR 2001; 50:120125.

133. Cousins MJ. Foreword. In Fordyce WE (ed). Back pain in the workplace: Management of disability in nonspecific conditions. Task Force Report. Seattle: IASP Press, 1995, p ix.

134. Lissovoy G, Brown RE, Halpern $M$ et al. Cost-effectiveness of long-term intrathecal morphine therapy for pain associated with failed back surgery syndrome. Clin Ther 1997; 19:96-112.

135. Bell G, Kidd D, North R. Cost-effectiveness analysis of spinal cord stimulation in treatment of failed back surgery syndrome. I Pain Symp Manage 1997; 13:286-295.

136. Turk DC. Clinical effectiveness and cost effectiveness of treatment for patients with chronic pain. Clin J Pain 2002; 18:355365 .

137. Straus BN. Chronic pain of spinal origin: the costs of intervention. Spine 2002; 27 : 2614-2620.

138. Rosenblum A, Joseph H, Fong C et al. Prevalence and characteristics of chronic pain among chemically dependent patients in methadone maintenance and residential treatment facilities. JAMA 2003; 289: 2370-2378.
139. Kentucky Drug Threat Assessment. National Drug Intelligence Center and Kentucky State Police. Product No. 2002SO382 KY-001, July 2002.

140. The KASPER Program. The KY Cabinet for Health Services. Department for Public Health.dphdrugcontrol@mail.state.ky.us.

141. Guidelines for prescribing controlled substances (Monitoring Medicine). J Ky Med Assoc 1998; 194:309-312.

142. Houck LK. The Drug Enforcement Administration, Controlled Substances and Pain Management. http://www.deadive rsion.usdoj.gov/pubs/nwslttr/spec2001/ page10.htm

143. Kentucky Board of Medical Licensure. Model guidelines for the use of controlled substances in pain treatment. J Ky Med Assoc 2001; 99:291-2944.

144. Considerations when prescribing benzodiazepines (Monitoring Medicine). J Ky Med Assoc 1998; 96:398.

145. The stimulant regulations: 201 KAR 9: 016. Restrictions on use of amphetamines and amphetamine-like anorectic controlled substances. Available at: www.state.ky.us/agencies/kbml.

146. The Benzodiazepines Guidelines. KMA Journal. Vol. 96. October 1998, p 398.

147. Mant A, de Burgh S, Yeo G et al. Anxiety $\&$ insomnia - think twice before prescribing. The Royal Australian College of General Practitioners, 1997.

148. Benzodiazepines: Some prescription guidelines. Connexions 1994; 14:17.

149. Robertson JR, treasure W. Benzodiazepine abuse. Nature and extent of the problem. CNS Drugs 1996; 5:137-146.

150. Garretty DJ, Wolff K, hay AW et al. Benzodiazepine misuse by drug addicts. Ann Clin Biochem 1997; 34:68-73.

151. Gelkopf M, Bleich A, Hayward R et al. Characteristics of benzodiazepine abuse in methadone maintenance treatment patients: A 1-year prospective study in an Israeli clinic. Drug Alcohol Depend 1999; 55:63-68.

152. Ellis P, Carney MW. Benzodiazepine abuse and management of anxiety in the community. Int J Addict 1988; 23:1083-1090.

153. Wolf B, Grohmann R, Biber D et al. Benzodiazepine abuse and dependence in psychiatric patients. Pharmacopsychiatry 1989; 22:54-60.

154. Schmidt LG, Grohmann R, Muller-Oerlinghausen $B$ et al. Prevalence of benzodiazepine abuse and dependence in psychiatric in-patients with different nosology. An assessment of hospital-based drug surveillance data. Br J Psychiatry 1989; 154:839843.

155. Miller NS, Gold MS. Identification and treatment of benzodiazepine abuse. Am Fam Phys 1989; 40:175-183.

156. Roth M. Anxiety disorders and the use and abuse of drugs. J Clin Psychiatry 1989; 50 : 30-35.

157. Landry MJ, Smith DE, Mcduff DR et al. Ben- zodiazepine dependence and withdrawal: Identification and medical management. J Am Board Fam Pract 1992; 5:167-176.

158. Monotti R. Emergencies related to substance abuse. Schweizerische Medizinische Wochenschrift 1993; 123:881886.

159. Obafunwa JO, Busuttil A. Deaths from substance overdose in the Lothian and Borders Region of Scotland. Hum Exp Toxicol 1994; 13:401-406.

16o. Lee KC, Chan TY, Chan AW et al. Use and abuse of benzodiazepines in Hong Kong 1990-1993 - The impact of regulatory changes. J Toxicol 1995; 33:597-602.

161. Maruta T, Swanson DW. Problems with the use of oxycodone compound in patients with chronic pain. Pain 1981; 11:389-396.

162. Turner JA, Calsyn DA, Fordyce WE et al. Drug utilization patterns in chronic pain patients. Pain 1982; 12:357-363.

163. Center on Addiction and Substance abuse. Substance abuse and federal entitlement programs. New York: Columbia University, 1995.

164. Falco M. Demand reduction. Proceedings of the inaugural symposium on crime and punishment in the United States. Washington, DC. United States Sentencing Commission, 1993, pp 243-249.

165. Held G. Linkages between substance abuse prevention and other human services. Literature Review June 1998, Part A.

166. The Economic Costs of Drug Abuse in the United States. Executive Office of the President. Office of National Drug Control Policy 1992-1998. September 2001.

167. www.sam h sa.gov/oas / d a w n/ htm\#Edcomp.

168. Rush AJ, Polatin P, Gatchel RJ. Depression and chronic low back pain. Spine 2000; 25:2566-2571.

169. Long DM, Debba MB, Torgerson WS et al. Persistent back pain and sciatica in the United States: Patient characteristics. J Spinal Disord 1996; 9:40-58.

170. Main CJ, Waddell G. Psychologic distress. In Waddell G (ed). The Back Pain Revolution. Churchill Livingstone, Philadelphia, 1998, pp 173-186.

171. Gatchel RJ, Turk DC. Preface. In Gatchel RJ, Turk DC (eds). Psychosocial Factors in Pain. The Guilford Press. New York, 1999, pp XIII-XIV.

171. Gatchel RJ. Perspectives on pain: A historical review. In Gatchel RJ, Turk DC (eds). Psychosocial Factors in Pain. The Guilford Press. New York, 1999, pp 3-17.

172. Manchikanti L, Fellows B, Pampati V et al. Comparison of psychological status of chronic pain patients and the general population: Pain Physician 2002; 5:40-48.

173. Manchikanti L, Pampati V. Research designs in interventional pain management: Is randomization superior, desirable or essential? Pain Physician 2002; 5 :in press.

174. Banks SM, Kerns RD. Explaining high rates of depression in chronic pain: A diathesis- 
stress framework. Psychol Bull 1996; 119: 95-110.

175. Manchikanti L, Pampati V, Damron K et al. Evaluation of psychological status in chronic low back pain: Comparison with general population. Pain Physician 2002; 5:149-155.

176. Manchikanti L, Pampati V, Beyer C et al. Do number of pain conditions influence emotional status? Pain Physician 2002; 5: 200-205.

177. Asmundson GJ, Jacobson SJ, Allerdings MD et al. Social phobia in disabled workers with chronic musculoskeletal pain. Behav Res Ther 1996; 34:939-943.

178. Atkinson JH, Slater MA, Patterson TL et al. Prevalence, onset, and risk of psychiatric disorders in men with chronic low back pain: A controlled study. Pain 1991; 45: 111-121.

179. Manchikanti L, Fellows B, Singh V. Understanding psychological aspects of chronic pain in interventional pain management. Pain Physician 2002; 5:57-82.

180. Manchikanti L, Pampati V, Fellows B et al. Characteristics of chronic low back pain in patients in an interventional pain management setting: A prospective evaluation. Pain 2001; 4:131-142.

181. Dersh J, Gatchel RJ, Polatin P. Chronic spinal disorders and psychopathology: Research findings and theoretical considerations. Spine 2001; 1:88-94.

182. Lee $M$. Update on analgesics for moderate-severe pain. Rx Quarterly 2002; 1:1-6.

183. Savage SR. Opioid use in the management of chronic pain. Med Clin North Am 1999; 83:761-786.

184. Janicki PK, Parris WC. Clinical pharmacology of opioids. In Smith H (ed). Drugs for Pain. Hanley \& Belfus, Inc., Phaldelphia, 2003, pp 97-118.

185. Kastrup TH. Drug Facts and Comparisons 2002. Wolters Kluwer Company, St. Louis, 2002.

186. Oda Y, Kharasch ED. Metabolism of methadone and levo-alpha-acetylmethadol (LAAM) by human intestinal cytochrome $\mathrm{P}_{450} 3 \mathrm{~A}_{4}$ (CYP3A4): potential contribution of intestinal metabolism to presystemic clearance and bioactivation. J Pharmacol Exp Ther 2001; 298:1021-1032.

187. Yue QY, Hasselstrom J, Svensson JO et al. Pharmacokinetics of codeine and its metabolites in Caucasian healthy volunteers: comparisons between extensive and poor hydroxylators of debrisoquine. $\mathrm{Br} / \mathrm{Clin}$ Pharmacol 1991; 31:635-642.

188. Yue QY, Svensson JO, Alm C et al. Codeine O-demethylation co-segregates with polymorphic debrisoquine hydroxylation. $\mathrm{Br}$ J Clin Pharmacol 1989; 28:639-645.

189. Professional's Handbook of Drug Therapy for Pain. Propoxyphene Hydrochloride. Springhouse Corp. Springhouse, 2001, pp 456-458.

190. The American Geriatrics Society (AGS). The management of persistent pain in old- er persons. JAGS 2002; 50:S205-S224.

191. Miller RR, Feingold A, Paxinos J. Propoxyphene hydrochloride. A critical review. JAMA 1970; 213:996-1006.

192. Li Wan Po A, Zhang WY. Systemic overview of the co-proxamol to assess analgesic effects of addition of dextropropoxyphene to paracetamol. BMJ 1997; 315:15651571.

193. Eckhardt K, Li S, Ammon S et al. Same incidence of adverse drug events after codeine administration irrespective of the genetically determined differences in morphine formation. Pain 1998; 76:27-33.

194. Levy MH. Advancement of opioid analgesia with controlled-release oxycodone. Eur I Pain 2001; 5:113-116.

195. Lewis KS, Han NH. Tramadol: A new centrally acting analgesic. Am J Health Syst Pharm 1997; 54:643-652.

196. Smith H (ed). Acetaminophen (bedside). In Drugs for Pain. Hanley \& Belfus, Inc., Phaldelphia, 2003, pp 33-40.

197. Professional's Handbook of Drug Therapy for Pain. Aspirin. Springhouse Corp. Springhouse, 2001, pp 93-96.

198. Professional's Handbook of Drug Therapy for Pain. Acetaminophen. Springhouse Corp. Springhouse, 2001, pp 75-78.

199. Arkinstall W, Sandler A, Goughnour B et al. Efficacy of controlled-release codeine in chronic non-malignant pain: A randomized, placebo-controlled clinical trial. Pain 1995; 62:169-178.

200. Jamison RN, Raymond SA, Slawsby EA et al. Opioid therapy for chronic noncancer back pain. A randomized prospective study. Spine 1998; 23:2591-2600.

201. Taub A. Opioid analgesics in the treatment of chronic intractable pain of non-neoplastic origin. In Kitahata LM, Collins D (eds.) Narcotic Analgesics in Anaesthesiology. Williams \& Wilkins, Baltimore, 1982, pp 199-208.

202. Portenoy RK, Foley KM. Chronic use of opioid analgesics in non-malignant pain: Report of 38 cases. Pain 1986; 25:171-186.

203. Tennant FS, Robinson D, Sagherian A et al. Chronic opioid treatment of intractable non-malignant pain. Pain Management 1988; Jan-Feb:18-36.

204. Hale ME, Fleischmann R, Salzman R et al. Efficacy and safety of controlled-release versus immediate-release oxycodone: Randomized, double-blind evaluation in patients with chronic back pain. Clin J Pain 1999; 15:179-183.

205. McNairy SL, Maruta T, Ivnik RJ et al. Prescription medication dependence and neuropsychologic function. Pain 1984; 18: 169-177.

206. Fordyce WE. Behavioral methods for chronic pain and illness. Mosby, St. Louis, 1976.

207. Schofferman J. Long-term use of opioid analgesics for the treatment of chronic pain of nonmalignant origin. J Pain Symptom Manage 1993; 8:279-288.
208. Lurie P, Lee PR. Fifteen solutions to the problems of prescription drug abuse. J Psychoactive Drugs 1991; 23:349-357.

209. Wesson DR, Smith DE. Prescription drug abuse. Patient, physician and cultural responsibilities. West J Med 1990; 152:613616.

210. Groer J, Brodsky M. The incidence of illicit drug use in the United States 1962-1989. BrJ Addict 1992; 87:1345.

211. Regier DA, Meyers JK, Dramer et al. The NIMH epidemiologic catchment area program. Arch Gen Psychiatry 1984; 41:934.

212. Steele-Rosomoff R, Fishbain DA, Goldberg $M$ et al. Chronic pain patients who lie in this psychiatric examination about current drug/alcohol use. Pain 1990; 5:S299.

213. Rafii A, Haller DL, Poklis A. Incidence of recreational drug use among chronic pain clinic patients [Abstract]. In: Meeting Abstracts, St. Louis, Missouri: American Pain Society, 1990:33.

214. Evans PJD. Narcotic addiction in patients with chronic pain. Anesthesia 1981; 36: 597-602.

215. Medina J, Diamond S. Drug dependency in patients with chronic headache. Headache 1977; 17:12-14.

216. Bannwarth B. Risk-benefit assessment of opioids in chronic noncancer pain. Drug Saf 1999; 21:283-296.

217. Crews JC. Multimodal pain management strategies for office-based and ambulato ry procedures. JAMA 2002; 288:629-632.

218. Cherny N, Ripamonti C, Pereira J et al. Strategies to manage the adverse effects of oral morphine: An evidence-based report. J Clin Oncol 2001; 19:2541-2554.

219. Joransen DE. Federal and state regulation of opioids. J Pain Symptom Manage 1990; 5:S12-25.

220. Jamison RN, Anderson KO, Peeters-Asdourian $C$ et al. Survey of opioid use in chronic nonmalignant pain patients. Reg Anesth $1994 ; 19: 225-230$.

221. Joranson DE. A new drug law for the states: An opportunity to affirm the role of opioids in cancer pain relief. J Pain Symptom Manage 1990; 5:333-336.

222. Portenoy RK. Chronic opioid therapy in nonmalignant pain. J Pain Symptom Manage 1990; 5:S46-S62.

223. Dunbar SA, Katz NP. Chronic opioid therapy for nonmalignant pain in patients with a history of substance abuse: Report of 20 cases. J Pain Symptom Manage 1996; 11: 163-171.

224. Melzack R. The tragedy of needless pain. Science 1990; 262:27-33.

225. Morgan JP, Pleet DL. Opiophobia in the United States: The underttreatment of severe pain. In Morgan JP, Kagan DV (eds). Society and Medication: Conflicting Signals for Prescribers and Patients. Lexington Press, Lexington, 1983; 313-326.

226. Portenoy RK. Opioid therapy in the management of chronic back pain. In Tollison CD (ed). Interdisciplinary Rehabilitation of 
Low Back Pain. Williams \& Wilkins, Baltimore, 1989, pp 137-157.

227. Porte JH, Jick J. Addiction rare in patients treated with narcotics. N Engl J Med 1980; 301:123.

228. Hollister LE, Müller-Oerlinghausen B, Rickels $\mathrm{K}$ et al. Clinical uses of benzodiazepines. J Clin Psychopharmacol 1993; 13: 1S-169S.

229. Woods JH, Katz JL, Winger GD. Abuse liability of benzodiazepines. Pharmacol Rev 1987; 39:251-419.

230. Woods JH, Katz JL, Winger GD. Benzodiazepines: use, abuse and consequences. Pharmacol Rev 1992; 44:151-347.

231. Robinson RC, Gatchel RJ, Polatin P et al. Screening for problematic prescription opioid use. Clin J Pain 2001; 17:220-228.

232. Lipman AG, Jackson KC. Use of opioids in chronic noncancer pain. Purdue Pharma, Norwalk, 2000, pp 1-12.

233. Kleber $\mathrm{H}$. The nosology of abuse and dependence. J Psychiatr Res 1990; 24:5764.

234. Diagnostic and Statistical Manual for Mental Disorders. Fourth Edition (DSM-IV). American Psychiatric Association. Washington, 1994 .

235. Sees KL, Clark HW. Opioid use in the treatment of chronic pain: Assessment of addiction. J Pain Symptom Manage 1993; 8: 257-264.

236. Compton P, Darakjian J, Miotto K. Screening for addiction in patients with chronic pain and "problematic" substance use: Evaluation of a pilot assessment tool. J Pain Symptom Manage 1998; 16:355-363.

237. Weissman DE, Haddox JD. Opioid pseudoaddiction - an iatrogenic syndrome. Pain 1989; 36:363-365.

238. American Society of Addiction Medicine. Public Policy Statement on Definitions Re- lated to the Use of Opioids in Pain Treament. http://www.ASAM.org.

239. Levy M. Pain management in advanced cancer. Semin Oncol 1985; 12:401-404.

240. Walsh T, Baxter R, Bowman $\mathrm{K}$ et al. High dose morphine and respiratory function in chronic cancer pain. Pain 1981; 39:S39.

241. Elliott JA, Opper SE. Opioids: Adverse effects and their management. In Smith HS (ed). Drugs for Pain. Hanley \& Belefus, Inc., Philadelphia, 2003, pp 133-152.

242. O'Brien CP. Drug addiction and abuse. In Goodman and Gilman's Pharmacologic Basis of Therapeutics. $10^{\text {th }}$ ed. McGrawHill, New York, 2001; pp 621-642.

243. De Leon-Casasola O, Yarussi A. Pathophysiology of opioid tolerance and clinical approach to the opioid-tolerant patient. Curr Rev Pain 2000; 4:203.

244. Santillan R, Hurle MA, Armijo JA et al. Nimodipine-enhanced opiate analgesia in cancer patients requiring dose escalation: A double-blind, placebo-controlled study. Pain 1998; 76:17.

245. Wallis BJ, Lord SM, Bogduk N. Resolution of psychological distress of whiplash patients following treatment by radiofrequency neurotomy: A randomized, double-blind, placebo-controlled trial. Pain 1997; 73:15-22.

246. Manchikanti L, Pampati VS, Bakhit C et al. Effectiveness of lumbar facet joint nerve blocks in chronic low back pain: A randomized clinical trial. Pain Physician 2001; 4: 101-117.

247. Manchikanti L, Pampati VS, Fellows B et al. Role of one day epidural adhesiolysis in management of chronic low back pain: A randomized clinical trial. Pain Physician 2001; 4:153-166.

248. Manchikanti L, Pampati VS, Rivera J et al. Effectiveness of percutaneous adhesioly- sis and hypertonic saline neurolysis in refractory spinal stenosis. Pain Physician 2001; 4:366-373.

249. Saal JA, Saal JS. Intradiscal electrothermal treatment for chronic discogenic low back pain: Prospective outcome study with a minimum 2-year follow-up. Spine 2002; 27:966-974.

250. Robinson R, Gatchel R, Polatin $P$ et al. Screening for problematic prescription opioid use. Clin J Pain 2001; 17:220-228.

251. Sees KL, Clark W. Opioid use in the treatment of chronic pain: assessment of addiction. J Pain Symptom Manage 1993; 8:257.

252. Fishbain DA, Rosomoff HL, Rosomoff RS. Drug abuse, dependence, and addiction in chronic pain patients. Clin J Pain 1992; 8: 77-85.

253. Katz N, Fanciullo G. Role of urine toxicology testing in the management of chronic opioid therapy. Clin J Pain 2002; 18:S76-S82.

254. Carroll KM. Methodological issues and problems in the assessment of substance use. Psychol Assess 1995; 7:349-358.

255. Preston KL, Silverman K, Schuster CR et al. Comparison of self-reported drug use with quantitative and qualitative urinalysis for assessment of drug use in treatment studies. NIDA Res Monogr 1997; 167:130-145.

256. Fishbain DA, Cutler RB, Rosomoff $\mathrm{HL}$ et al. Validity of self-reported drug use in chronic pain patients. Clin J Pain 1999; 15:184191.

257. Belgrade M. Urine toxicology testing in patients with chronic pain. Abstract presented at the American Pain Society Annual Meeting. Phoenix, AZ. April 2001.

258. 1997 Documentation Guidelines for Evaluation and Management Services. http:// www.cms.gov/medlearn/emdoc.htm 